\title{
Crop residues exacerbate the negative effects of extreme flooding on soil quality
}

\author{
Antonio R. Sánchez-Rodríguez ${ }^{1}$ (D) Paul W. Hill ${ }^{1} \cdot$ David R. Chadwick $^{1}$ • \\ Davey L. Jones ${ }^{1}$
}

Received: 29 March 2017 / Revised: 17 May 2017 / Accepted: 26 May 2017 / Published online: 19 June 2017

(C) The Author(s) 2017. This article is an open access publication

\begin{abstract}
Extreme flood events are predicted to have a negative impact on soil quality. Currently, there is a lack of information about the effect of agricultural practices on soil functioning and microbial processes under these events. We hypothesized that the impact of flooding on soil quality will be exacerbated when crop residues are present in the soil as they will induce more extreme anaerobicity. A spring extreme flood event $\left(10^{\circ} \mathrm{C}\right.$, 9 weeks) was simulated in mesocosms containing an arable sandy-loam soil low in nutrients. The main treatments were (1) with and without flooding and (2) with and without maize residue addition $\left(8 \mathrm{Mg} \mathrm{ha}^{-1}\right)$. We monitored changes in soil chemical quality indicators (e.g. $\mathrm{pH}$, salinity, $\mathrm{Fe}^{3+}, \mathrm{P}, \mathrm{C}, \mathrm{NH}_{4}{ }^{+}, \mathrm{NO}_{3}{ }^{-}$ and organic $\mathrm{N}$ ), greenhouse gas (GHG) emissions $\left(\mathrm{CO}_{2}, \mathrm{CH}_{4}\right.$, $\mathrm{N}_{2} \mathrm{O}$ ) and soil microbial community composition (PLFAs) during a prolonged flood period ( 9 weeks) and an 8-week "recovery" period after flooding. In comparison to the other treatments, flooding in the presence of crop residues resulted in a dramatic drop in soil redox potential. This was associated with the enhanced release of $\mathrm{Fe}$ and $\mathrm{C}$ into solution and an increase in $\mathrm{CH}_{4}$ emissions. In contrast, maize residues reduced potential nitrate losses and $\mathrm{N}_{2} \mathrm{O}$ emissions, possibly due to complete denitrification and microbial $\mathrm{N}$ immobilization. Both flooding and maize residues stimulated microbial growth and promoted a shift in microbial community composition. Following floodwater removal, most of the soil quality
\end{abstract}

Electronic supplementary material The online version of this article (doi:10.1007/s00374-017-1214-0) contains supplementary material, which is available to authorized users.

Antonio R. Sánchez-Rodríguez

afs42a@bangor.ac.uk

1 School of Environment, Natural Resources and Geography, Bangor University, Bangor, Gwynedd LL57 2UW, UK indicators returned to the levels of the control treatment within 5 weeks. After this short recovery phase, no major impact of flooding could be observed on plant growth (maize pot-grown). Overall, we conclude that both extreme flooding and management regime negatively impact upon a range of soil quality indicators (e.g. redox, GHG emissions); however, the soil showed high resilience and recovered quickly after floodwater removal. Further work is required to investigate the impact of repeated extreme flood events on soil quality and function over longer timescales.

Keywords Iron · Nitrogen mineralization · Nutrient cycling · Phosphorus $\cdot$ Methane $\cdot$ Nitrous oxide $\cdot$ Waterlogging

\section{Introduction}

Although controversial, there is increasing evidence to suggest that climate change is already causing an increased frequency of extreme flood events in some regions of the world (Pall et al. 2011; Slater and Villarini 2016). However, as warming temperatures amplify the atmosphere's water holding capacity, it is widely agreed that the occurrence of extreme precipitation and flooding events will increase (WMO 2013; Volosciuk et al. 2016; Yuan et al. 2017). This is likely to have a major impact on food security, ecosystem functioning and human health (Mirza 2011; Tong et al. 2016). It is therefore important to understand how these extreme events may impact upon soil functioning and how we may be able to better manage soils to prevent a loss in ecosystem service provision.

While many soils on floodplains regularly suffer from inundation, the increased magnitude of flood events means that new areas with no recent history of flooding are now becoming severely affected (Yellen et al. 2014). In addition, these extreme floods can result in floodwater remaining on the land 
for several weeks or months, and in some cases up to several metres in depth (Natural England 2014). In terms of a loss in natural capital, the worst-case scenario occurs when the floodwater is moving laterally across the landscape facilitating the erosive loss of large quantities of topsoil (Li and Wei 2014; Boardman and Vandaele 2016). Typically, however, floodwater remains stationary on the soil, although this can still be subject to wind-driven turbulence within the overlying water column. Surface flooding can be expected to cause considerable losses in soil quality and plant productivity as well as inducing changes in nutrient cycling, meso- and macrofaunal abundance and microbial community composition (Bossio and Scow 1998; Niu et al. 2014). It is also likely that the impact of flooding on soil quality will be heavily influenced by both past and present management regimes (e.g. fertilizer additions, presence of organic residues, plant cover). To minimize the consequences, work is therefore needed to identify management practices which may exacerbate the negative effects of long-term flooding, and identify strategies that may increase resilience.

Sustainable agricultural practices typically involve the use of crop residues as a soil amendment to increase organic matter content, promote soil $\mathrm{C}$ sequestration, provide erosion control and improve nutrient cycling. Crop residues are rich in $\mathrm{C}$ but also represent a source of other nutrients (e.g. N, P). The availability of these nutrients to plants and microorganisms, however, depends on their relative concentrations and speed of turnover. In most arable systems, organic residues in the form of straw or stubble are largely incorporated into the soil at the end of the growing season or in the spring. These residues typically contain low levels of $\mathrm{N}$ and $\mathrm{P}$ which may ultimately lead to net immobilization and a reduction of available nutrients in the soil (Damon et al. 2014). In some situations, this may have positive benefits as it may reduce $\mathrm{NO}_{3}{ }^{-}$ leaching; however, this effect is not always observed (Doring et al. 2005; Hansen et al. 2015). The effect of cereal residues on greenhouse gas emissions (GHG), particularly $\mathrm{N}_{2} \mathrm{O}$ fluxes, is also controversial (Chen et al. 2013). Specifically, they may increase nitrification under aerobic conditions (Frimpong and Baggs 2010), and provide energy for denitrifiers facilitating denitrification under anaerobic conditions, both of which can produce $\mathrm{N}_{2} \mathrm{O}$ (Davidson 1991). Crop residue quality appears to be inversely related to $\mathrm{N}_{2} \mathrm{O}$ emissions with high $\mathrm{C}: \mathrm{N}$ ratio residues producing lower emissions (Li et al. 2013). In addition, $\mathrm{CH}_{4}$ emissions may also result from $\mathrm{C}$-rich crop residues, particularly under waterlogged conditions (Devevre and Horwath 2000).

In the context of current climate change, the main aim of this experiment was to investigate how soils with no previous history of flooding respond and recover from an extreme flood event. In addition, the secondary aim was to investigate whether the presence of crop residues accelerated the decline in soil quality. We hypothesize that high $\mathrm{C}$-to- $\mathrm{N}$ ratio cereal residues would reduce
$\mathrm{N}_{2} \mathrm{O}$ emissions but increase $\mathrm{CH}_{4}$ emissions during flooding. Further, we hypothesized that shifts in soil chemistry and microbial community composition during flooding would cause lasting damage to the soil leading to a loss of function in terms of its ability to support primary productivity.

\section{Materials and methods}

\section{Soil and maize residue characterization}

A sandy textured Eutric Cambisol (FAO 2015) was collected from the surface (0-20 cm depth) Ahp horizon of an arable field located in Worcestershire, England ( $52^{\circ} 6^{\prime} 23.5 \mathrm{~N}, 2^{\circ} 13^{\prime}$ $39.5 \mathrm{~W}$; Fig. S1). The soil was typical of those inundated during the extreme flood event experienced in the winter of 2013-2014 (Fig. S2 A; Met Office 2014; Muchan et al. 2015), but was collected above the flood line and had no recent history of flooding (Fig. S2 B).

To characterize the soil, replicate batches of soil $(n=3)$ were air-dried $\left(25^{\circ} \mathrm{C}\right)$ and passed through a $2-\mathrm{mm}$ sieve. The $\mathrm{pH}$ and the electrical conductivity (EC) were determined in a 1:2.5 $(w / v)$ soil:distilled water suspension with standard electrodes. The $\mathrm{pH}$ was $6.4 \pm 0.1$ and the EC was $1.4 \pm 0.1 \mathrm{dS} \mathrm{m}^{-1}$. Soil solution was extracted from the soil using the centrifugation-drainage method of Giesler and Lundström (1993) and soluble N determined spectrophotometrically on a PowerWave-XS microplate reader (BioTek Instruments Inc., Winooski, VT) according to Mulvaney (1996) for $\mathrm{NH}_{4}^{+}$and Miranda et al. (2001) for $\mathrm{NO}_{3}{ }^{-}$. The $\mathrm{NH}_{4}{ }^{+}$and $\mathrm{NO}_{3}{ }^{-}$concentrations were $1.0 \pm 0.2 \mathrm{mg} \mathrm{N}^{-1}$ and nitrate $63.4 \pm 4.4 \mathrm{mg} \mathrm{l}^{-1}$ respectively. Total $\mathrm{C}$ and $\mathrm{N}$ were determined using a TruSpec $\AA$ analyser (Leco Corp., St Joseph, MI) and found to be $3.03 \pm 0.01 \mathrm{~g} \mathrm{C} \mathrm{kg}^{-1}$ and $0.67 \pm 0.01 \mathrm{~g} \mathrm{~N} \mathrm{~kg}^{-1}$ $(\mathrm{C}: \mathrm{N}$ ratio, 4.5). The maize residues (stubble) were collected at the end of the growing season after crop senescence (Fig. S3). The residues were air-dried $\left(20^{\circ} \mathrm{C}\right)$ and cut up into 1-2-cm-long pieces for use in the experiments. The total $\mathrm{C}$ content of the stubble was $495 \pm 1 \mathrm{~g} \mathrm{C} \mathrm{kg}^{-1}$ and the total $\mathrm{N}$ was $5.22 \pm 0.08 \mathrm{~g}$ $\mathrm{N} \mathrm{kg}^{-1}$ (on a dry weight basis; $\mathrm{C}: \mathrm{N}$ ratio, 94:1).

\section{Experimental design}

Sixteen transparent polypropylene containers $(11 \times 8 \mathrm{~cm}$ base, $27 \mathrm{~cm}$ high; Lock \& Lock Ltd., Seoul, Republic of Korea) without drainage holes were filled with $900 \mathrm{~g}$ of field-moist soil sieved to pass $1 \mathrm{~cm}$. Chopped pieces of maize residue were then mixed with the soil in half the mesocosms at a rate of $8 \mathrm{Mg} \mathrm{ha}^{-1}$ $\left(7 \mathrm{~g} \mathrm{mesocosm}^{-1}\right.$ ), reflecting typical farm practice (AHDB 2015). For the non-destructive removal of soil water, a Rhizon ${ }^{\circledR}$ sampler (Rhizosphere Research Products, Wageningen, The Netherlands) was inserted into the centre of the soil in each mesocosm at an angle of $45^{\circ}$ and depth of $7 \mathrm{~cm}$. The soil was left unplanted to simulate the spring fallow period 
of the maize agronomic cycle (AHDB 2015). The containers were transferred to a constant-temperature room and incubated at $10{ }^{\circ} \mathrm{C}$ in the dark to simulate winter/spring conditions. Dark conditions were used to simulate the restricted light conditions experienced in spring floods (due to particles in the water column; Fig. S2). After a week of pre-flood incubation, distilled water was added to 8 of the 16 mesocosms, 4 with maize residue and 4 without maize residue, to give a 10-cm floodwater depth above the soil surface. The experiment therefore had 4 treatments in a factorial design:

(1) Control or no-residue addition without flood (NR)

(2) No-residue addition with flood (NR + F)

(3) Maize residue addition without flood (MR)

(4) Maize residue addition with flood $(M R+F)$

There were four replicates per treatment. The floodwater was maintained at a constant depth (by addition of distilled water) for 9 weeks after which it was removed. Soil moisture in the non-flooded treatments was maintained at $70-80 \%$ of field capacity by adding distilled water weekly (determined via weight loss).

To simulate a late spring flood recovery phase, all the mesocosms were transferred to a climate-controlled Fitotron ${ }^{\circledR}$ plant growth cabinet (Weiss Technik UK Ltd., Ebbw Vale, UK) maintained at $15{ }^{\circ} \mathrm{C}$ in the day and $10{ }^{\circ} \mathrm{C}$ at night, with a photoperiod of $18 \mathrm{~h} \mathrm{day}^{-1}$, light intensity of $350 \mu \mathrm{mol} \mathrm{m} \mathrm{m}^{-2} \mathrm{~s}^{-1}$ and relative humidity of $70 \%$, for 8 weeks. The previously flooded mesocosms were allowed to naturally dry out to the level of the unflooded treatments. Watering was not applied to all treatments during the last 2 weeks of the soil recovery stage to reduce the soil moisture prior to undertaking the final crop establishment phase of the experiment.

To evaluate the post-effect of flooding on plant performance, soil from each flood mesocosm was recovered and placed in individual 1-1 plastic pots. Four pre-germinated (72 h) maize seedlings (Zea mays L.) were then planted in each of the 16 pots. After 7 days, the plants were thinned to leave two plants per pot. To fertilize the plants, a nutrient solution containing $10 \mathrm{mM} \mathrm{KNO}_{3}$ and $15 \mathrm{mM} \mathrm{KH}_{2} \mathrm{PO}_{4}$ was added to each pot at a rate of $40 \mathrm{ml} \mathrm{pot}^{-1}$ week $^{-1}$ (5.6 $\mathrm{kg} \mathrm{N} \mathrm{ha}^{-1}$ and $19.6 \mathrm{~kg} \mathrm{P} \mathrm{ha}^{-1}$, in total). The plants were grown for 4 weeks at which point they were harvested. The conditions in which the maize plants grew were the same as those detailed for the late spring flood recovery phase except the temperature during the day $\left(20^{\circ} \mathrm{C}\right)$.

\section{Soil chemical indicators}

Soil solution using a Rhizon® sampler $(0.15 \mu \mathrm{m}$ pore size $)$ and floodwater using a pipette were collected on a weekly basis during the flood experiment. $\mathrm{pH}$ was measured using a Model 209 pH meter (Hanna Instruments Ltd., Leighton Buzzard, UK) and EC using a Jenway 4520 conductivity meter (Cole-Parmer Ltd., Stone, UK). Fe (Loeppert and Inskeep 1996), P (Murphy and Riley 1962), $\mathrm{NH}_{4}{ }^{+}$(Mulvaney 1996) and $\mathrm{NO}_{3}{ }^{-}$(Miranda et al. 2001) were measured by spectrophotometry on a PowerWave-XS microplate reader, and total dissolved organic $\mathrm{C}$ (DOC) and total dissolved N (TDN) using a Multi N/C 2100/2100 analyser (AnalytikJena AG, Jena, Germany). Dissolved organic N (DON) was calculated by subtraction of $\mathrm{NO}_{3}{ }^{-}$and $\mathrm{NH}_{4}{ }^{+}$from the TDN value. The last sampling was performed 13 weeks after flooding. Oxidation-reduction potential at a soil depth of $3 \mathrm{~cm}$ was determined periodically throughout the experiment using a WTW SenTix ${ }^{\circledR}$ probe (Xylem Analytics Ltd., Letchworth, UK). The potential losses of nutrients were calculated as the amount of nutrient released into the soil solution and floodwater $\left(C_{\text {release }}\right)$ as follows:

$$
\begin{aligned}
C_{\text {release }}\left(\mathrm{mg} \text { container }^{-1}\right)= & {\left[C_{\text {sol }} \times V_{\text {soil }} \times \Theta\right] } \\
& +\left[C_{\text {flood }} \times V_{\text {flood }}\right]
\end{aligned}
$$

where $C_{\mathrm{sol}}$ is the concentration of nutrient in the soil solution, $C_{\text {flood }}$ is the concentration in floodwater, $V_{\text {soil }}$ and $V_{\text {flood }}$ are the volume of soil (0.70 1) and floodwater (0.88 1), respectively, and $\Theta$ is the volumetric water content $\left(0.5 \mathrm{~cm}^{3} \mathrm{~cm}^{-3}\right)$.

\section{Soil greenhouse gas emissions}

Greenhouse gas (GHG) samples were taken weekly during the flood experiment except for the 10th week after flooding in which two samples were taken (before and after removal of the water). At each sampling event, gas-tight lids containing a Suba-Seal® gas sampling port (Sigma-Aldrich Ltd., Poole, UK) were placed on the mesocosms. Headspace gas samples from each mesocosm were then removed using a syringe and placed into pre-evacuated vials at 0 and $1 \mathrm{~h}$. Methane, $\mathrm{CO}_{2}$ and $\mathrm{N}_{2} \mathrm{O}$ concentrations in the vials were determined by gas chromatography using a Clarus $500 \mathrm{GC}$ with a Turbomatrix (HS-40) autoanalyser (PerkinElmer Inc., Waltham, $\mathrm{MA}$ ). $\mathrm{CH}_{4}$ and $\mathrm{CO}_{2}$ were measured with a flame ionization detector (FID) connected to a methanizer and $\mathrm{N}_{2} \mathrm{O}$ by a ${ }^{63} \mathrm{Ni}$ electron-capture detector. Daily fluxes were estimated as the slope of the linear regression between concentrations at the two times taking into account the temperature and the ratio between chamber volume and soil surface area (MacKenzie et al. 1998). Cumulative fluxes were estimated by linear interpolations between two measurements of daily fluxes and adding the amount to the previous cumulative total. The global warming potential (GWP) of $\mathrm{CH}_{4}, \mathrm{CO}_{2}$ and $\mathrm{N}_{2} \mathrm{O}$ was estimated in $\mathrm{CO}_{2}$ equivalents by multiplying the cumulative fluxes at the end of the experiment by $34-\mathrm{CH}_{4}, 1-\mathrm{CO}_{2}$ and 298- $\mathrm{N}_{2} \mathrm{O}$ before summing them, as a means of comparing the GWP of the different gases, and to be able to explore the effect of the different treatments on the total GHG emission (IPCC 2013). 


\section{Soil microbial community analysis}

After the flood stage and at the end of the experiment, soil samples $(25 \mathrm{~g})$ were removed from each mesocosm and stored at $-80{ }^{\circ} \mathrm{C}$ for microbial community analysis. Phospholipid fatty acid analysis (PLFA) was undertaken according to the method of Bartelt-Ryser et al. (2005) with taxonomic groups ascribed to individual PLFAs using the Sherlock® PLFA Method and Tools Package (PLFAD1; Microbial ID Inc., Newark, DE). A total of 70 fatty acids were found in our soil samples but we only chose those that represented more than $0.5 \%$ of the total PLFA for biomarker and taxonomic group annotation (Ratledge and Wilkinson 1988; Kieft et al. 1994; Paul and Clark 1996; Olsson et al. 1999; Zelles 1999; Madan et al. 2002; Niklaus et al. 2003; Bartelt-Ryser et al. 2005; Table 1).

\section{Plant analysis}

At the end of the post-flooding maize growth trial, leaf chlorophyll concentration was estimated using a SPAD 502 Portable Chlorophyll Meter (Minolta Camera Co., Osaka, Japan). In addition, leaf chlorophyll was extracted with $10 \mathrm{ml}$ methanol from $1-\mathrm{cm}^{2}$ pieces of young leaves (two per pot) and determined according to Wintermans and de Mots (1965). SPAD and leaf chlorophyll concentration per unit of surface were highly correlated $(r=0.95, p<0.001)$; therefore, the SPAD value was adopted as a reliable proxy for chlorophyll concentration. At harvest, plant height was recorded and the roots and shoots separated and their dry weights determined by oven drying $\left(80^{\circ} \mathrm{C}, 48 \mathrm{~h}\right)$. Nutrient concentrations in shoots and roots were determined after dry-ashing and $\mathrm{HCl}$ digestion (Adrian 1973) using a 700-ES Series ICP-OES
(Varian Inc., Palo Alto, CA) except $\mathrm{C}$ and $\mathrm{N}$, using a TruSpec® analyser (Leco Corp., St Joseph, MI).

\section{Statistical analysis}

Repeated-measures analysis of variance (rANOVA) based on a completely randomized design with four treatments (combination of factors, NR, NR + F, MR, MR + F) was performed for $\mathrm{pH}, \mathrm{EC}, \mathrm{Fe}, \mathrm{P}, \mathrm{NH}_{4}{ }^{+}, \mathrm{NO}_{3}{ }^{-}, \mathrm{TN}$ and $\mathrm{DOC}$, in soil solution, for soil oxidation-reduction potential and for daily $\mathrm{GHG}$ fluxes, and with two treatments for floodwater $(\mathrm{NR}+\mathrm{F}$ and $\mathrm{MR}+\mathrm{F}$. Bonferroni multiple comparison test at a probability level of 0.05 was used to detect differences between treatments. Analysis of variance (ANOVA) based on a completely randomized factorial design with two factors (flood and maize residue) was applied to cumulative GHG fluxes and PLFAs (total amount and taxonomic groups) for the flood experiment, and to SPAD, plant height, plant dry weight and total amount of nutrients in the maize shoots and roots from the pot experiment. Tukey's test was used to find differences between factors at a probability level of 0.05 . Principal component analysis (PCA) was used to explore relationships between combinations of factors and taxonomic groups (PLFAs). Additional Pearson correlations were used to explore relationships between variables. STATISTIX 10.0 software (Analytical Software, Tallahassee, FL) was used for all the analyses except for the PCA (taxonomic groups-PLFAs) which was performed in R' with the Vegan package to include additional variables as environmental factors (daily GHG fluxes, nutrients in soil solution, redox in soil) based on multiple regression with principal components (PCs). Significance was assessed by the permutation test.

Table 1 Fatty acids ( $>0.5 \%$ of the total PLFAs) considered in the study as microbial biomarkers for the different taxonomic groups

\begin{tabular}{|c|c|c|}
\hline Biomarker & Taxonomic group & References \\
\hline $\begin{array}{l}\text { 14:0 iso, } 15: 0 \text { iso, } 15: 0 \text { anteiso, } 15: 1 \text { iso w6c, } \\
15: 1 \text { iso w9c, } 16: 0 \text { iso, } 17: 0 \text { iso, } \\
17: 0 \text { anteiso, } 17: 1 \text { iso w9c }\end{array}$ & Prokaryotes: Gram+ bacteria & $\begin{array}{l}\text { Ratledge and Wilkinson (1988), Kieft et al. (1994), } \\
\text { Paul and Clark (1996), Zelles (1999), Olsson et al. } \\
\text { (1999), Bartelt-Ryser et al. (2005), Zelles (1999) }\end{array}$ \\
\hline $\begin{array}{l}\text { 16:1w5c, } 16: 1 w 7 c, 16: 1 w 9 c, 17: 1 w 8 c, \\
\text { 17:0 cyclo w7c, } 18: 1 w 5 c, 18: 1 \text { w9c, } \\
\text { 18:1w7c, 19:0 cyclo w7c }\end{array}$ & Prokaryotes: Gram- bacteria & $\begin{array}{l}\text { Kieft et al. (1994), Paul and Clark (1996), } \\
\text { Zelles (1999) }\end{array}$ \\
\hline $\begin{array}{l}\text { 16:0 } 10 \text { methyl, 17:0 } 10 \text { methyl, } \\
\text { 17:1w7c } 10 \text { methyl, 18:0 } 10 \text { methyl, } \\
\text { 18:1w7c } 10 \text { methyl }\end{array}$ & $\begin{array}{l}\text { Prokaryotes: actinomycetes, } \\
\text { Gram+ bacteria }\end{array}$ & Zelles (1999) \\
\hline 15:0 DMA & Prokaryotes: anaerobic bacteria & \\
\hline 20:4w6 & Eukaryotes: protozoa & Paul and Clark (1996) \\
\hline $18: 2 w 6 c$ & Eukaryotes: fungi & Paul and Clark (1996) \\
\hline $16: 1 \mathrm{w} 5 \mathrm{c}$ & $\begin{array}{l}\text { Eukaryotes: putative arbuscular } \\
\text { mycorrhizas, fungi }\end{array}$ & Olson et al. (1999), Madan et al. (2002) \\
\hline $\begin{array}{l}14: 0,15: 0,16: 0,17: 0,18: 0 \\
20: 0,22: 0,24: 0\end{array}$ & Not assigned to a taxonomic group & Ratledge and Wilkinson (1988), Niklaus et al. (2003) \\
\hline
\end{tabular}




\section{Results}

\section{Soil pH, electrical conductivity (EC) and soil oxidation-reduction potential}

Significant alterations in soil solution $\mathrm{pH}$ over the course of the experiment were observed in all treatments $(p<0.001$ except 11 weeks after flooding when $p=0.444$ ). The addition of maize residues resulted in an initial increase in soil $\mathrm{pH}$, for MR during the flood phase and for MR $+\mathrm{F}$ at the end of the soil recovery period (Fig. 1a). A general increase in soil solution $\mathrm{pH}$ occurred for $\mathrm{NR}+\mathrm{F}$ throughout the experiment; however, less change was seen in the NR treatment. At the end of the flood recovery phase, significant differences were still apparent between treatments. After week 1, the $\mathrm{pH}$ of the floodwater progressively increased over the duration of the flood for both treatments ( $p<0.005$; Fig. 1b).

Changes in soil EC in response to flooding proved highly dependent upon maize residue application, with significant effects seen within 4 weeks of flooding and persisting to the end of the soil recovery phase $(p<0.005)$. For example, EC decreased in the NR $+\mathrm{F}$ treatment while it increased in the $\mathrm{MR}+\mathrm{F}$ treatment (Fig. 1c). In comparison to the unamended control treatment (NR), maize residue addition in the absence of flooding (MR) reduced the EC by ca. $50 \%$. A progressive increase in floodwater EC was also observed in both flood treatments, although this was significantly greater in the presence of maize residues ( $p<0.005$; Fig. 1d).

No treatment differences in soil oxidation-reduction potential were apparent at the start of the experiment $(p=0.989)$;
Fig. 1 Temporal dynamics of $\mathrm{pH}$ (a, b), electrical conductivity (EC) $(\mathbf{c}, \mathbf{d})$ and redox potential $(\mathbf{e})$ of soil and overlying floodwater in response to flooding and crop residue addition $\left(8 \mathrm{Mg} \mathrm{ha}^{-1}\right)$. Values represent means \pm SEM $(n=4)$. Vertical bars in the upper part of the figure represent Bonferroni values for significant differences at $\alpha=0.05$. The vertical lines indicate the separation between pre-flood, flood and soil recovery phases. $N R$ control without flood or residues, $N R+F$ no residues with flooding, $M R$ maize residue application, $M R+F$ maize residue with flooding (a)

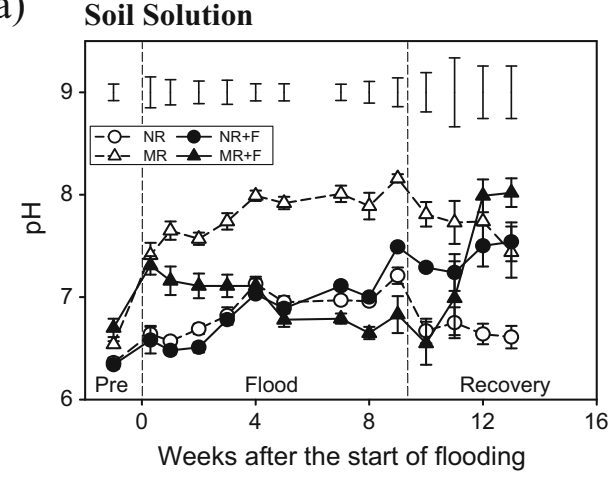

(c)

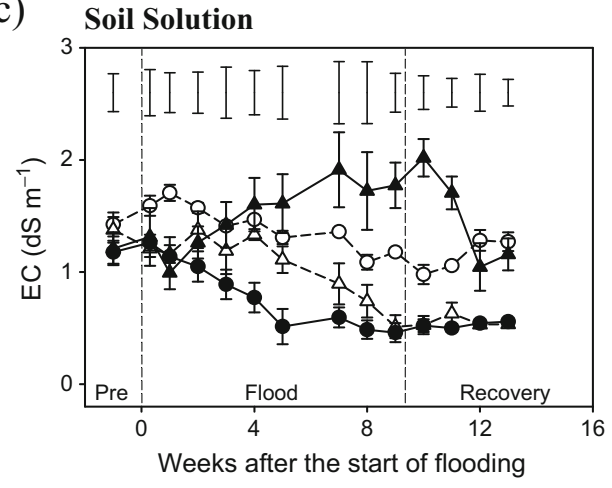

(e)

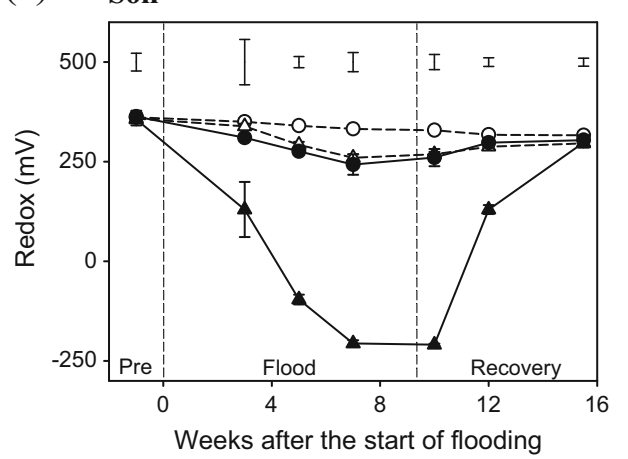

Soil (b) Floodwater

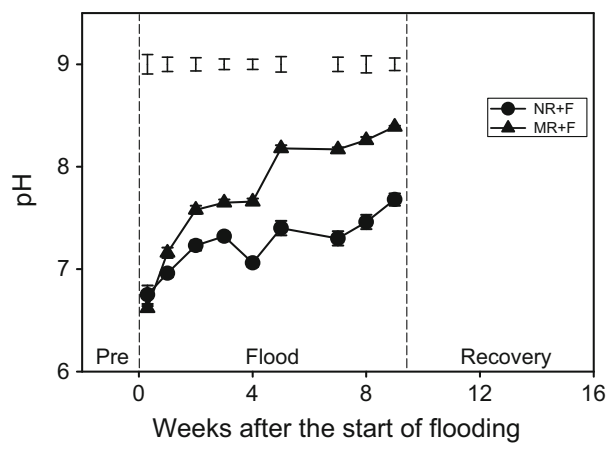

(d) Floodwater

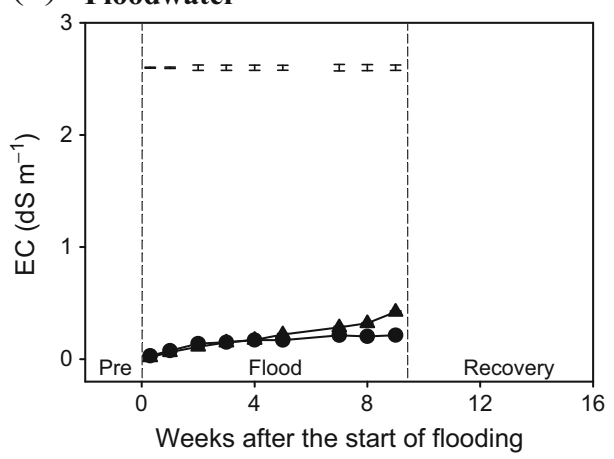


however, after flooding, oxidation-reduction potential dramatically reduced in the MR $+\mathrm{F}$ treatment relative to the other treatments. Redox potential was also slightly reduced in the $\mathrm{MR}$ and $\mathrm{NR}+\mathrm{F}$ treatments relative to the unamended control (Fig. 1e), particularly from weeks 5 to 10 after flooding $(p<0.001)$. No significant treatment differences in soil oxidation-reduction potential were found at the end of the flood recovery phase ( $p=0.182$; Fig. 1e).

\section{Soil nutrient dynamics and potential losses}

We observed the precipitation of large quantities of $\mathrm{Fe}(\mathrm{OH})_{3}$ on the container walls of all the flooded mesocosms. A very large increase in soluble $\mathrm{Fe}$, particularly in the $\mathrm{MR}+\mathrm{F}$ treatment, was also observed during flooding $(p<0.005)$; however, these levels rapidly fell to background within 3 weeks of floodwater removal (Fig. 2a). Initially, the floodwater contained elevated levels of $\mathrm{Fe}$; however, these decreased in both treatments with increasing flood duration (Fig. 2b).

Maize residue addition progressively reduced soil solution $\mathrm{P}$ concentrations in the unflooded treatments. In contrast, no significant differences were observed for the NR, NR $+F$ and $\mathrm{MR}+\mathrm{F}$ treatments during flooding. In the $\mathrm{MR}+\mathrm{F}$ treatment, however, removal of floodwater did stimulate a loss of $\mathrm{P}$ from solution. At the end of the soil recovery phase, $\mathrm{P}$ concentrations were significantly lower in treatments which had received maize residues, irrespective of flooding $(p<0.001$;
Fig. 2c). The concentrations of $\mathrm{P}$ in floodwater and soil solution were similar; however, generally smaller concentrations of $\mathrm{P}$ were observed in floodwater from the $\mathrm{MR}+\mathrm{F}$ treatment than in the NR $+\mathrm{F}$ treatment $(p<0.05$; Fig. $2 \mathrm{~d})$.

Maize residue application initially resulted in higher soil solution $\mathrm{NH}_{4}{ }^{+}$concentrations ( $p=0.008$; Fig. 3a); however, over the duration of the experiment, $\mathrm{NH}_{4}{ }^{+}$levels fell in all treatments and remained low until the end of the experiment. Consistently low $\mathrm{NH}_{4}{ }^{+}$concentrations $\left(<0.5 \mathrm{mg} \mathrm{N} \mathrm{I}^{-1}\right)$ were also observed in the floodwater with no significant treatment effects observed (Fig. 3b). The initial soil solution concentration of $\mathrm{NO}_{3}{ }^{-}$was high in all treatments with no significant treatment differences observed. However, $\mathrm{NO}_{3}{ }^{-}$concentrations in the maize residue treatments quickly reached very low levels, especially in the flooded treatment (Fig. 3c). This decrease in $\mathrm{NO}_{3}{ }^{-}$was also observed in the $\mathrm{NR}+\mathrm{F}$ treatment during the flood phase. Similarly to soil, maize residue application reduced floodwater $\mathrm{NO}_{3}{ }^{-}$concentrations relative to the unamended mesocosms. Overall, floodwater $\mathrm{NO}_{3}{ }^{-}$concentrations increased in the $\mathrm{NR}+\mathrm{F}$ treatment and remained low in the MR + F treatment $(p<0.05$; Fig. 3d).

There was a large increase in soil solution DOC concentrations in the $\mathrm{MR}+\mathrm{F}$ treatment relative to the MR treatment and especially in comparison to the NR and NR $+F$ treatments. For both maize residue treatments, a reduction in DOC was observed after floodwater removal (Fig. 3e). At the end of the flood recovery phase, the concentration of DOC was similar in
Fig. 2 Temporal dynamics of soil solution $\mathrm{Fe}(\mathbf{a}, \mathbf{b})$ and $\mathrm{P}(\mathbf{c}, \mathbf{d})$ in response to flooding and crop residue addition $\left(8 \mathrm{Mg} \mathrm{ha}^{-1}\right)$. Values represent means \pm SEM $(n=4)$. Vertical bars in the upper part of the figure represent Bonferroni values for significant differences at $\alpha=0.05$. The vertical lines indicate the separation between pre-flood, flood and soil recovery phases. $N R$ control without flood or residues, $N R+F$ no residues with flooding, $M R$ maize residue application, $M R+F$ maize residue with flooding (a)

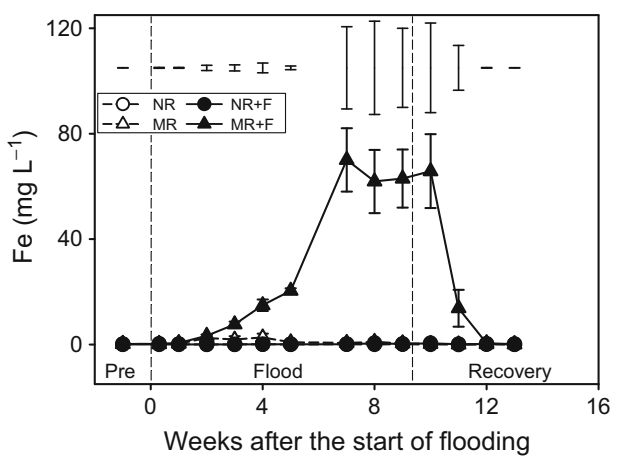

(c)

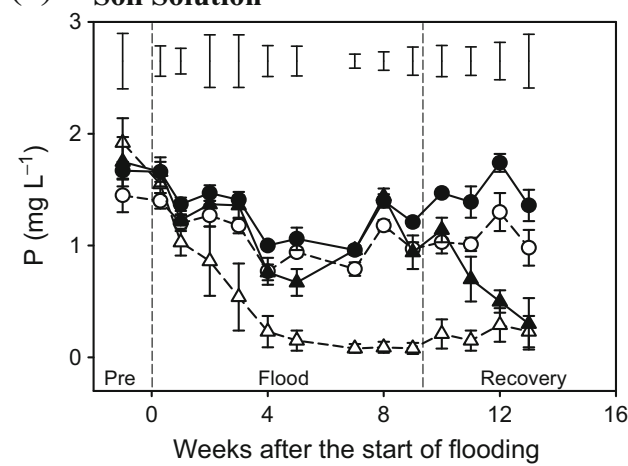

(b) Floodwater

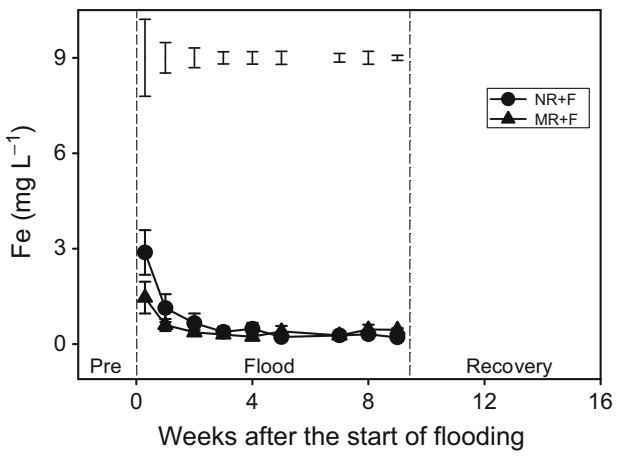

(d) Floodwater

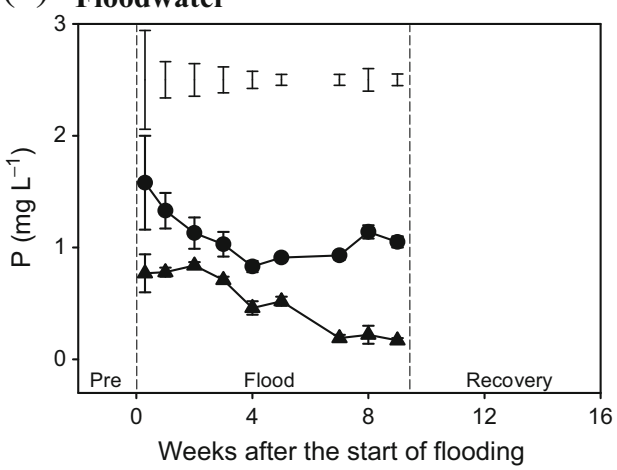


Fig. 3 Temporal dynamics of soil solution $\mathrm{NH}_{4}^{+}(\mathbf{a}, \mathbf{b}), \mathrm{NO}_{3}^{-}(\mathbf{c}, \mathbf{d})$, $\operatorname{DOC}(\mathbf{e}, \mathbf{f})$ and DON $(\mathbf{g}, \mathbf{h})$ in response to flooding and crop residue addition $\left(8 \mathrm{Mg} \mathrm{ha}^{-1}\right)$. Values represent means \pm SEM $(n=4)$. Vertical bars in the upper part of the figure represent Bonferroni values for significant differences at $\alpha=0.05$. The vertical lines indicate the separation between pre-flood, flood and soil recovery phases. $N R$ control without flood or residues, $N R+F$ no residues with flooding, $M R$ maize residue application, $M R+F$ maize residue with flooding
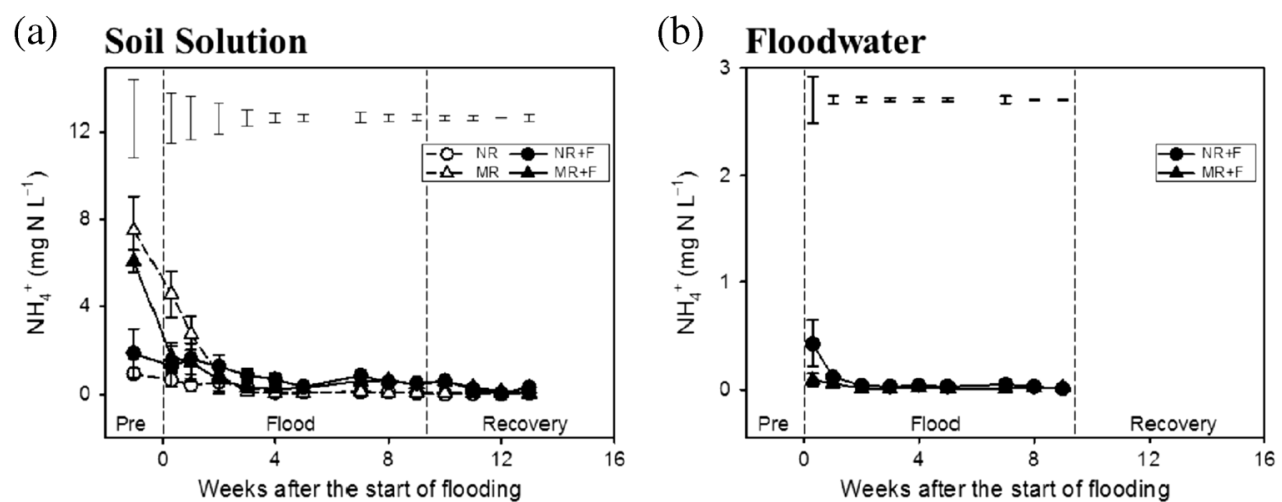

(c) Soil Solution

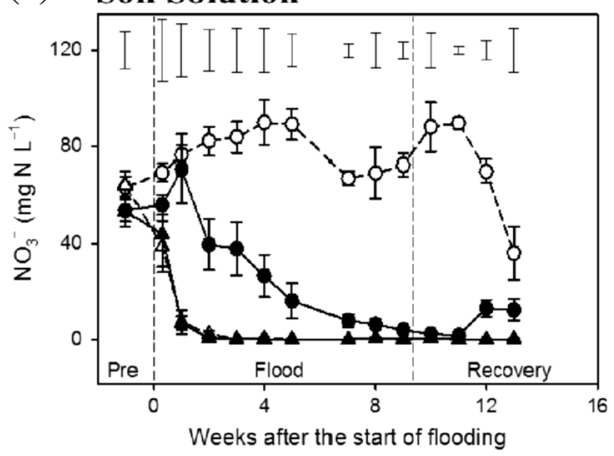

(d) Floodwater

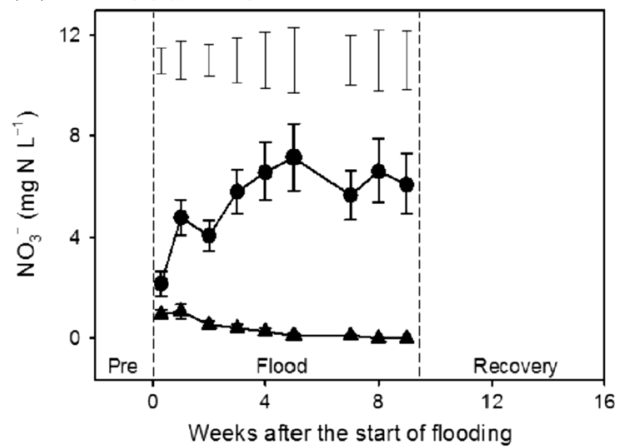

(f) Floodwater

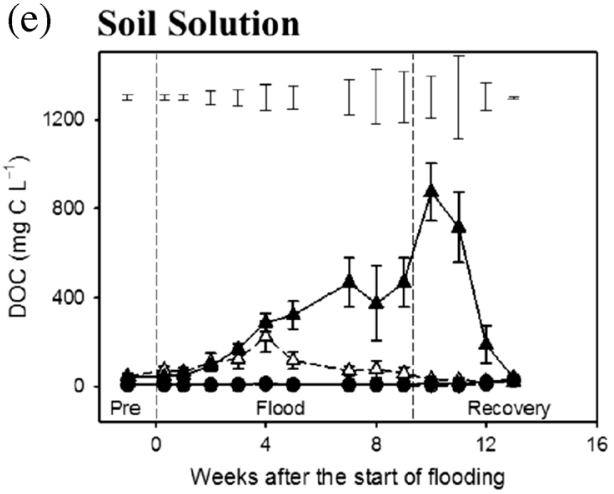

(g) Soil Solution

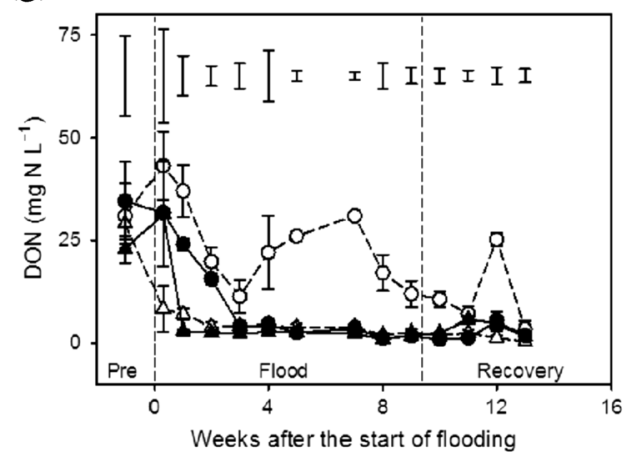

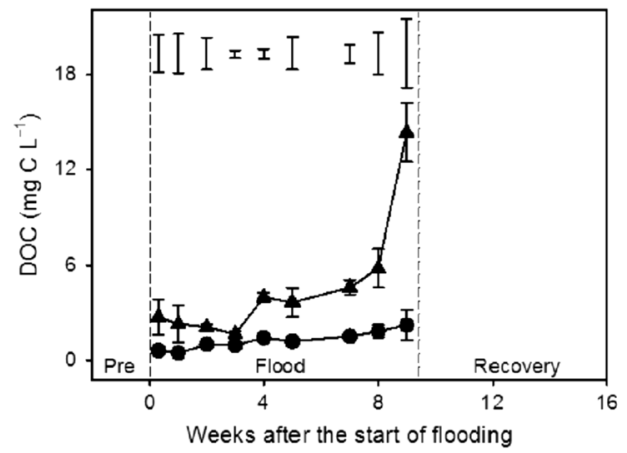

(h) Floodwater

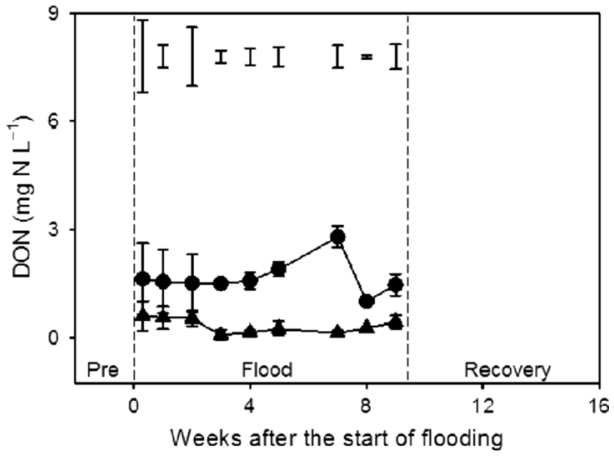

all treatments $(p=0.089)$. Floodwater DOC concentrations were also significantly higher in the mesocosms amended with maize residues ( $p<0.05$; Fig. 3f). The pattern of DOC and DON in the different floodwater treatments followed a similar trend to that of DOC and DON in soil solution although the concentrations were much lower (Figs. 3f-h). 
Table 2 summarizes the potential losses of nutrients in response to flooding and the presence of maize crop residues. Overall, flooding caused a significant increase in potential losses for all nutrients. In addition, maize residue treatments resulted in greater potential losses of $\mathrm{Fe}, \mathrm{NH}_{4}{ }^{+}$and $\mathrm{C}$ but a decrease in $\mathrm{NO}_{3}{ }^{-}$. An interaction occurred between flood and maize residue for $\mathrm{C}$ with the potential losses following the order $\mathrm{NR}<\mathrm{NR}+\mathrm{F}<\mathrm{MR}<\mathrm{MR}+\mathrm{F}$.

\section{Soil GHG emissions}

Daily GHG fluxes throughout the experiment are shown in Fig. 4. Methane release was only detectable in the MR + F treatment at the end of the flood phase and during the first 4 weeks of soil recovery (Fig. 4a). In the MR treatment, peak $\mathrm{CO}_{2}$ emissions occurred in the first few weeks following residue addition, although this was suppressed in the presence of floodwater (Fig. 4b). In the case of $\mathrm{N}_{2} \mathrm{O}$, emissions were low in comparison with the other two GHGs but some peaks were observed in the NR $+\mathrm{F}$ and NR treatments in the first few weeks (Fig. 4c). The overall effect of flooding and maize residue incorporation on GHG emissions and GWP is shown in Table 3. Overall, GWP followed the series

$\mathrm{NR}+\mathrm{F}<\mathrm{NR}<\mathrm{MR}<\mathrm{MR}+\mathrm{F}(p=0.060)$

Table S1 displays the correlations between soil parameters and GHG fluxes during the flood and soil recovery stages. Of notable importance are the relationships between oxidationreduction potential and nutrient release $\left(\mathrm{Fe}, \mathrm{NH}_{4}{ }^{+}, \mathrm{DOC}\right)$ and GHG fluxes $\left(\mathrm{CH}_{4}\right.$ and $\left.\mathrm{CO}_{2}\right)$ during flooding and with $\mathrm{N}_{2} \mathrm{O}$ in the flood recovery phase. In addition, there were strong relationships between $\mathrm{pH}$ and nutrient concentration (EC, $\mathrm{Fe}, \mathrm{P}, \mathrm{NO}_{3}{ }^{-}$) during flooding.

\section{Soil microbial community composition}

The two factors, flood and maize residue, increased microbial biomass (total PLFA) at the two sampling times (Table 4). These differences were driven by an increase in the amount of Gram- bacteria and anaerobic bacteria (anaerobes); however, actinomycetes and fungi were both reduced by flooding. Gram- bacteria, anaerobes, protozoa and fungi (after the flood phase) were positively affected, actinomycetes negatively (both samplings), and putative arbuscular mycorrhiza (AM) decreased during flooding but increased during the soil recovery phase in the presence of maize residues (Table 4). Total microbial biomass (PLFAs) and the majority of individual fatty acids were positively correlated with EC, Fe, DOC, $\mathrm{CH}_{4}$ and $\mathrm{CO}_{2}$ when analysed at the end of the flood phase and $\mathrm{pH}$ after the soil recovery, but negatively with soil oxidation-reduction potential and $\mathrm{NO}_{3}{ }^{-}$(both samplings), $\mathrm{P}$ and $\mathrm{N}_{2} \mathrm{O}$ after the soil recovery phase (Table $\mathrm{S} 2$ ).

Figure 5 shows the PCA for the taxonomic groups (PLFAs) and their relationship to environmental variables. The first PC, which explained $60.3 \%$ of total variance, is related with abundances of Gram- bacteria in one direction and abundances of actinomycetes and Gram+ bacteria in the opposite direction. The second PC, which explained $32.9 \%$ of the variance, is related to abundances of protozoa, fungi and anaerobe in one direction and abundances of Gram- and Gram+ bacteria in the other. The variables most strongly related to the first two PCs are oxidation-reduction potential $\left(p<0.001, r^{2}=0.47\right)$, $\mathrm{CO}_{2}\left(p=0.002, r^{2}=0.54\right), \mathrm{DOC}\left(p=0.003, r^{2}=0.34\right), \mathrm{NO}_{3}{ }^{-}$

Table 2 Factorial analysis of potential losses of nutrients (mean \pm standard error, $n=8$ recipients per factor, 4 replications per combination of factors) as a function of the flood and maize residue addition at the end of the experiment

\begin{tabular}{|c|c|c|c|c|c|c|c|}
\hline Factor & & $\mathrm{Fe}\left(\mathrm{kg} \mathrm{ha}^{-1}\right)$ & $\mathrm{P}\left(\mathrm{kg} \mathrm{ha}^{-1}\right)$ & $\mathrm{NH}_{4}^{+}\left(\mathrm{kg} \mathrm{ha}^{-1}\right)$ & $\mathrm{NO}_{3}^{-}\left(\mathrm{kg} \mathrm{ha}^{-1}\right)$ & $\operatorname{DON}\left(\mathrm{kg} \mathrm{ha}^{-1}\right)$ & $\mathrm{C}\left(\mathrm{kg} \mathrm{ha}^{-1}\right)$ \\
\hline \multirow[t]{2}{*}{ Flood } & $\mathrm{C}$ & $0.42 \pm 0.18 \mathrm{~b}$ & $0.36 \pm 0.03 b$ & $0.92 \pm 0.33 \mathrm{~b}$ & $16.69 \pm 1.35 b$ & $8.28 \pm 1.07 \mathrm{~b}$ & $26.5 \pm 10.5 b$ \\
\hline & $\mathrm{F}$ & $18.58 \pm 7.95 \mathrm{a}$ & $2.11 \pm 0.27 \mathrm{a}$ & $2.04 \pm 0.34 \mathrm{a}$ & $30.43 \pm 3.88 \mathrm{a}$ & $17.85 \pm 2.40 \mathrm{a}$ & $225.4 \pm 87.5 \mathrm{a}$ \\
\hline$P$ & & $<0.001$ & $<0.001$ & 0.008 & 0.002 & 0.004 & $<0.001$ \\
\hline \multirow[t]{2}{*}{ Maize residue } & NR & $1.67 \pm 0.79 b$ & $1.39 \pm 0.47$ & $0.82 \pm 0.31 b$ & $28.00 \pm 4.31 \mathrm{a}$ & $14.80 \pm 2.15$ & $10.7 \pm 2.5 \mathrm{~b}$ \\
\hline & MR & $17.33 \pm 8.28 \mathrm{a}$ & $1.08 \pm 0.26$ & $2.14 \pm 0.32 \mathrm{a}$ & $19.14 \pm 2.49 b$ & $11.33 \pm 2.82$ & $241.3 \pm 82.5 \mathrm{a}$ \\
\hline \multirow[t]{5}{*}{$P$} & & $<0.001$ & 0.238 & 0.003 & 0.027 & 0.216 & $<0.001$ \\
\hline & NR & $0.08 \pm 0.03$ & $0.31 \pm 0.02$ & $0.25 \pm 0.08$ & $19.67 \pm 1.03$ & $10.36 \pm 1.14$ & $5.2 \pm 0.1 \mathrm{~d}$ \\
\hline & $\mathrm{NR}+\mathrm{F}$ & $3.27 \pm 1.10$ & $2.48 \pm 0.49$ & $1.39 \pm 0.46$ & $36.31 \pm 6.28$ & $19.24 \pm 2.67$ & $16.1 \pm 3.0 \mathrm{c}$ \\
\hline & MR & $0.78 \pm 0.28$ & $0.41 \pm 0.05$ & $1.60 \pm 0.47$ & $13.71 \pm 1.21$ & $6.21 \pm 1.07$ & $47.8 \pm 14.8 \mathrm{~b}$ \\
\hline & $\mathrm{MR}+\mathrm{F}$ & $33.89 \pm 11.71$ & $1.74 \pm 0.15$ & $2.69 \pm 0.23$ & $24.56 \pm 2.79$ & $16.46 \pm 4.30$ & $434.6 \pm 81.2 \mathrm{a}$ \\
\hline Interaction $(P)$ & & 0.943 & 0.129 & 0.950 & 0.428 & 0.800 & 0.049 \\
\hline
\end{tabular}

Different letters indicate differences according to Tukey's HSD test at a probability level of 0.05 . All values for soluble $\mathrm{N}$ are given on an equivalent kilogram $\mathrm{N}$ per hectare basis. Bold indicates significant at $p<0.05$

$C$ control without flood, $F$ flood, $N R$ no-residue application, $M R$ maize residue application $\left(8 \mathrm{Mg} \mathrm{ha}^{-1}\right)$ 
(a) Daily fluxes

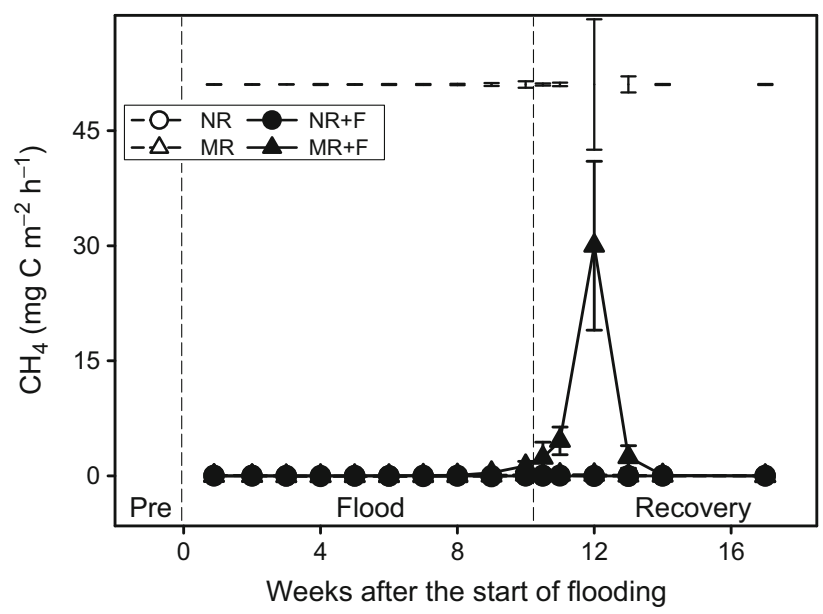

(b)

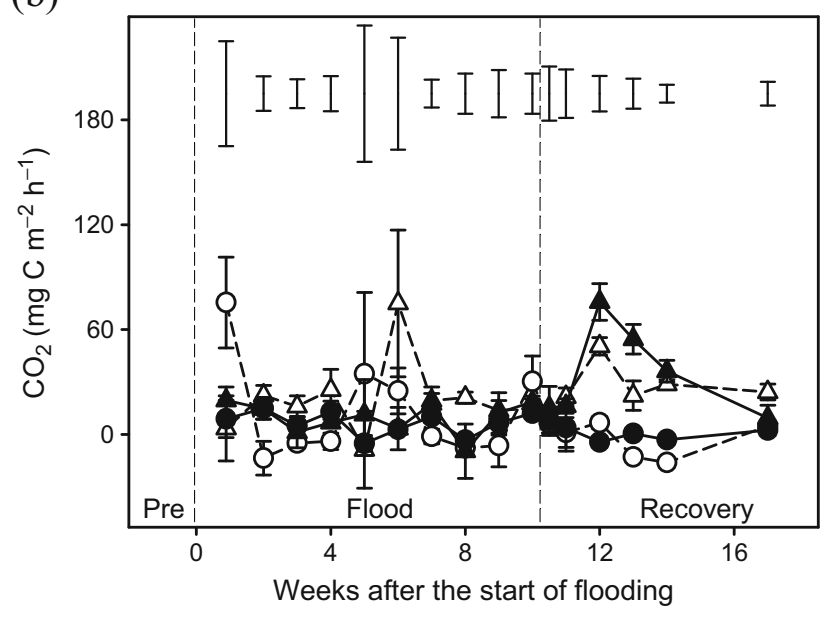

(c)

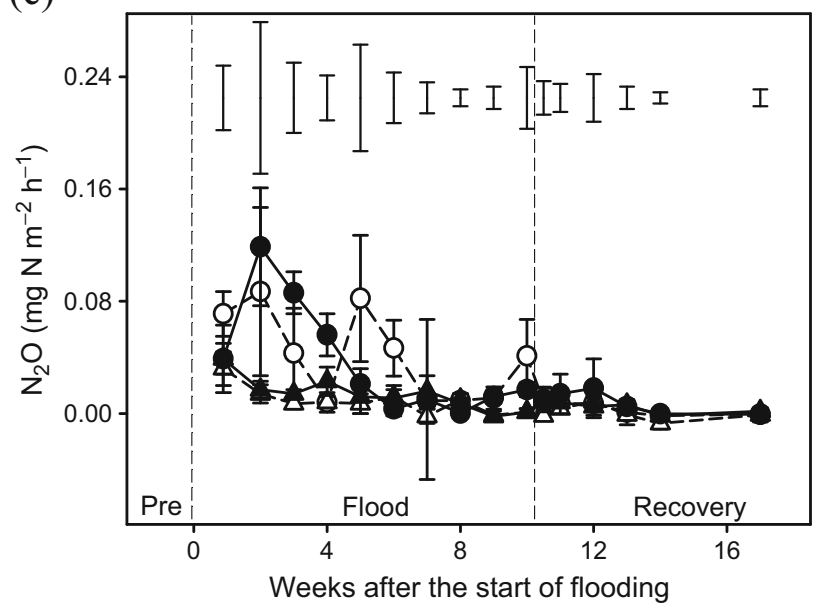

Fig. 4 Daily fluxes of greenhouse gases $\left(\mathbf{a ~ C H} \mathrm{CH}_{4}, \mathbf{b ~ C O} \mathrm{CO}_{2}\right.$ and $\left.\mathbf{c} \mathrm{N}_{2} \mathrm{O}\right)$ from soil in response to flooding and crop residue addition $\left(8 \mathrm{Mg} \mathrm{ha}^{-1}\right)$. Values represent means \pm SEM $(n=4)$. Vertical bars in the upper part of the figure represent Bonferroni values for significant differences at $\alpha=0.05$. The vertical lines indicate the separation between pre-flood, flood and soil recovery phases. $N R$ control without flood or residues, $N R+F$ no residues with flooding, $M R$ maize residue application, $M R+F$ maize residue with flooding $\left(p=0.006, r^{2}=0.30\right), \mathrm{CH}_{4}\left(p=0.028, r^{2}=0.28\right), \mathrm{Fe}$ $\left(p=0.017, r^{2}=0.27\right), \mathrm{P}\left(p=0.017, r^{2}=0.24\right)$ and $\mathrm{EC}$ $\left(p=0.042, r^{2}=0.20\right)$ (Fig. 5a). The PCA was able to clearly separate the soil treatments by time along PC1. Soil samples collected after the flood phase were below the $x$-axes (Fig. 5b), but the majority of those collected after the soil recovery phase were located above (Fig. 5c).

\section{Post-flooding maize growth trial}

At the final harvest, plant dry weight followed the series $\mathrm{NR}>\mathrm{MR}+\mathrm{F}>\mathrm{MR}>\mathrm{NR}+\mathrm{F}(p=0.050$; Table 5). The lowest SPAD values were obtained for plants grown on the $\mathrm{NR}+\mathrm{F}$ soil samples. Overall, maize residue application reduced the $\mathrm{N}$ content of the shoots and roots $(p=0.018$ and $p=0.001$, Table S3) while increasing the shoot-to-root ratio $(p=0.013)$. In contrast, flooding appeared to have little effect on plant performance or nutrient content (Table 5, Table S3).

\section{Discussion}

\section{Soil solution chemistry}

Here, we show that the chemistry of an arable soil with no known history of flooding responds very quickly to extreme waterlogging. Of importance, however, is that almost all of the soil chemical quality indicators studied showed reversible changes, returning back to levels seen in the corresponding control treatments within weeks of floodwater removal. Our study therefore demonstrates the resilience of soil to extreme winter flooding events, although this should be extrapolated to other soil types with caution (Hueso et al. 2011; de Vries et al. 2012). We further conclude that the presence of cereal residues in combination with flooding appears to be far more influential in regulating soil chemistry than flooding alone. Lastly, the soil chemical responses to waterlogging seen in our soil mirrored those frequently seen in soils with a long history of waterlogging (e.g. Gleysols, Fluvisols; Kyuma 2004; Rinklebe et al. 2016), suggesting that existing information on hydromorphic soils may be useful in predicting the impact of extreme flooding in soils rarely exposed to flooding.

Flooding did, however, increase the potential for nutrient losses (e.g. $\mathrm{NO}_{3}{ }^{-}, \mathrm{DON}, \mathrm{P}, \mathrm{C}$ ). In addition, flooding caused a redistribution of $\mathrm{Fe}$ within the soil. At the end of the flood period, it was apparent that $\mathrm{Fe}$ had migrated from the anoxic subsurface layers and re-precipitated as Fe-oxyhydroxides at the soil surface. This was most apparent in the residue treatments where the presence of labile $\mathrm{C}$ fuels a drop in oxidationreduction potential and the reduction and release of $\mathrm{Fe}^{2+}$ (Gotoh and Patrick 1974). We had expected that $\mathrm{P}$ would be released from the surface of $\mathrm{Fe}$ minerals when they were reduced; however, there was no evidence to support this. We 
Table 3 Cumulative GHG fluxes and global warming potential (GWP, in equivalent $\mathrm{g}$ of $\mathrm{CO}_{2}$; mean \pm standard error, $n=8$ recipients per factor, 4 replications per combination of factors) as a function of flood and maize residue addition at the end of the experiment

\begin{tabular}{llllll}
\hline Factor & & $\mathrm{CH}_{4} \mathrm{~kg} \mathrm{Cha}^{-1}$ & $\mathrm{CO}_{2} \mathrm{~kg} \mathrm{C} \mathrm{ha}^{-1}$ & $\mathrm{~N}_{2} \mathrm{O} \mathrm{kg} \mathrm{N} \mathrm{ha}$ & $\mathrm{GWP} \mathrm{kg} \mathrm{Cha}^{-1}$ \\
\hline Flood & $\mathrm{C}$ & $0.47 \pm 0.45 \mathrm{~b}$ & $403 \pm 111$ & $0.40 \pm 0.14$ & $537 \pm 105$ \\
& $\mathrm{~F}$ & $26.1 \pm 14.1 \mathrm{a}$ & $315 \pm 87$ & $0.39 \pm 0.10$ & $1318 \pm 541$ \\
$P$ & & $\mathbf{0 . 0 3 8}$ & 0.232 & 0.943 & 0.081 \\
Maize residue & $\mathrm{NR}$ & $0.05 \pm 0.23 \mathrm{~b}$ & $123 \pm 39 \mathrm{~b}$ & $0.63 \pm 011 \mathrm{a}$ & $313 \pm 65 \mathrm{~b}$ \\
& $\mathrm{MR}$ & $26.5 \pm 14.0 \mathrm{a}$ & $595 \pm 57 \mathrm{a}$ & $0.15 \pm 0.03 \mathrm{~b}$ & $1542 \pm 484 \mathrm{a}$ \\
$P$ & & $\mathbf{0 . 0 3 3}$ & $<\mathbf{0 . 0 0 1}$ & $\mathbf{0 . 0 0 2}$ & $\mathbf{0 . 0 1 1}$ \\
& $\mathrm{NR}$ & $-0.18 \pm 0.34 \mathrm{~b}$ & $148 \pm 77$ & $0.69 \pm 0.18$ & $348 \pm 124 \mathrm{~b}$ \\
& $\mathrm{NR}+\mathrm{F}$ & $0.29 \pm 0.31 \mathrm{~b}$ & $98 \pm 29$ & $0.57 \pm 0.15$ & $277 \pm 61 \mathrm{~b}$ \\
& $\mathrm{MR}$ & $1.13 \pm 0.73 \mathrm{~b}$ & $658 \pm 95$ & $0.10 \pm 0.04$ & $726 \pm 111 \mathrm{ab}$ \\
& $\mathrm{MR}+\mathrm{F}$ & $51.9 \pm 21.9 \mathrm{a}$ & $531 \pm 61$ & $0.21 \pm 0.03$ & $2358 \pm 800 \mathrm{a}$ \\
Interaction $(P)$ & & $\mathbf{0 . 0 4 1}$ & 0.598 & 0.363 & 0.060 \\
\hline
\end{tabular}

Different letters indicate differences according to Tukey's HSD test at a probability level of 0.05 . GWP for $\mathrm{CH}_{4}$ is 34 , and that for $\mathrm{N}_{2} \mathrm{O}$ is 298 (IPCC, 2013). Bold indicates significant at $p<0.05$

$C$ control without flood, $F$ flood, $N R$ no-residue application, $M R$ maize residue application $\left(8 \mathrm{Mg} \mathrm{ha}^{-1}\right)$ speculate that any released $\mathrm{P}$ was either re-sorbed onto $\mathrm{Al}(\mathrm{OH})_{3}$, migrated to the soil surface where it re-precipitated with Fe or was immobilized by the growing microbial community (Bünemann et al. 2012; Damon et al. 2014). All of

Table 4 Total amount of PLFAs (nmol g $\left.{ }^{-1}\right)$ and taxonomic groups (\%; mean \pm standard error, $n=8$ recipients per factor, 4 replications per combination of factors) as a function of flood and maize residue addition at the end of the experiment

\begin{tabular}{|c|c|c|c|c|c|c|c|c|c|}
\hline & & $\begin{array}{l}\text { Microbial PLFAs } \\
\left(\mathrm{nmol} \mathrm{g}^{-1}\right)\end{array}$ & $\begin{array}{l}\text { Gram+ } \\
\text { bacteria }(\%)\end{array}$ & $\begin{array}{l}\text { Gram-- } \\
\text { bacteria (\%) }\end{array}$ & $\begin{array}{l}\text { Actinomycetes } \\
(\%)\end{array}$ & $\begin{array}{l}\text { Anaerobes } \\
(\%)\end{array}$ & $\begin{array}{l}\text { Protozoa } \\
(\%)\end{array}$ & $\begin{array}{l}\text { Arb. myco. } \\
(\%)\end{array}$ & $\begin{array}{l}\text { Fungi } \\
\%\end{array}$ \\
\hline \multicolumn{10}{|l|}{ After flood stage } \\
\hline \multirow[t]{2}{*}{ Flood } & $\mathrm{C}$ & $16.7 \pm 1.0 \mathrm{~b}$ & $31.0 \pm 0.5$ & $44.2 \pm 1.0 \mathrm{~b}$ & $17.1 \pm 0.8 \mathrm{a}$ & $1.4 \pm 0.2 \mathrm{~b}$ & $0.5 \pm 0.1$ & $4.1 \pm 0.1$ & $1.8 \pm 0.1 \mathrm{a}$ \\
\hline & $\mathrm{F}$ & $20.4 \pm 2.3 \mathrm{a}$ & $30.7 \pm 0.9$ & $46.0 \pm 1.4 \mathrm{a}$ & $15.5 \pm 1.3 \mathrm{~b}$ & $1.8 \pm 0.1 \mathrm{a}$ & $0.6 \pm 0.2$ & $3.9 \pm 0.1$ & $1.5 \pm 0.1 \mathrm{~b}$ \\
\hline$P$ & & 0.022 & 0.542 & 0.003 & $<0.001$ & 0.003 & 0.305 & 0.087 & 0.018 \\
\hline \multirow[t]{2}{*}{ Maize residue } & NR & $14.5 \pm 0.3 \mathrm{~b}$ & $32.5 \pm 0.3 \mathrm{a}$ & $41.2 \pm 0.3 \mathrm{~b}$ & $19.0 \pm 0.1 \mathrm{a}$ & $1.3 \pm 0.1 \mathrm{~b}$ & $0.3 \pm 0.2 \mathrm{~b}$ & $4.2 \pm 0.1 \mathrm{a}$ & $1.5 \pm 0.1 \mathrm{~b}$ \\
\hline & MR & $22.7 \pm 1.5 \mathrm{a}$ & $29.2 \pm 0.5 \mathrm{~b}$ & $49.0 \pm 0.9 \mathrm{a}$ & $13.5 \pm 0.6 \mathrm{~b}$ & $1.9 \pm 0.1 \mathrm{a}$ & $0.8 \pm 0.1 \mathrm{a}$ & $3.8 \pm 0.1 \mathrm{~b}$ & $1.8 \pm 0.1 \mathrm{a}$ \\
\hline \multirow[t]{5}{*}{$P$} & & $<0.001$ & $<0.001$ & $<0.001$ & $<0.001$ & $<0.001$ & 0.011 & $<0.001$ & 0.024 \\
\hline & NR & $14.3 \pm 0.6 \mathrm{c}$ & $32.1 \pm 0.4 \mathrm{ab}$ & $41.6 \pm 0.4 \mathrm{c}$ & $19.3 \pm 0.1 \mathrm{a}$ & $1.0 \pm 0.1 \mathrm{c}$ & $0.1 \pm 0.1$ & $4.2 \pm 0.1 \mathrm{a}$ & $1.6 \pm 0.1 \mathrm{ab}$ \\
\hline & MR & $19.1 \pm 0.6 \mathrm{~b}$ & $29.9 \pm 0.4 \mathrm{bc}$ & $46.7 \pm 0.5 b$ & $14.9 \pm 0.3 \mathrm{~b}$ & $1.8 \pm 0.1 \mathrm{a}$ & $0.8 \pm 0.1$ & $4.0 \pm 0.1 \mathrm{ab}$ & $2.0 \pm 0.1 \mathrm{a}$ \\
\hline & $\mathrm{NR}+\mathrm{F}$ & $14.6 \pm 0.3 \mathrm{c}$ & $32.8 \pm 0.4 \mathrm{a}$ & $40.9 \pm 0.4 \mathrm{c}$ & $18.8 \pm 0.2 \mathrm{a}$ & $1.5 \pm 0.1 \mathrm{~b}$ & $0.4 \pm 0.3$ & $4.2 \pm 0.1 \mathrm{a}$ & $1.4 \pm 0.1 \mathrm{~b}$ \\
\hline & $\mathrm{MR}+\mathrm{F}$ & $26.2 \pm 1.4 \mathrm{a}$ & $28.5 \pm 0.9 \mathrm{c}$ & $51.2 \pm 0.7 \mathrm{a}$ & $12.1 \pm 0.4 \mathrm{c}$ & $2.0 \pm 0.1 \mathrm{a}$ & $0.8 \pm 0.1$ & $3.7 \pm 0.1 \mathrm{~b}$ & $1.6 \pm 0.2 \mathrm{ab}$ \\
\hline Interaction $(P)$ & & 0.123 & 0.093 & $<0.001$ & 0.001 & 0.161 & 0.520 & 0.199 & 0.386 \\
\hline \multicolumn{10}{|l|}{ After soil recovery } \\
\hline \multirow[t]{2}{*}{ Flood } & $\mathrm{C}$ & $22.9 \pm 1.7$ & $26.1 \pm 0.4$ & $43.9 \pm 1.3$ & $15.1 \pm 0.6$ & $3.7 \pm 0.7$ & $2.6 \pm 0.3$ & $4.0 \pm 0.1$ & $4.6 \pm 0.3$ \\
\hline & $\mathrm{F}$ & $26.8 \pm 2.1$ & $26.2 \pm 0.9$ & $45.3 \pm 1.1$ & $14.7 \pm 0.7$ & $2.9 \pm 0.5$ & $3.0 \pm 0.8$ & $3.7 \pm 0.1$ & $4.2 \pm 0.7$ \\
\hline$P$ & & 0.052 & 0.975 & 0.116 & 0.600 & 0.367 & 0.602 & 0.065 & 0.576 \\
\hline \multirow[t]{2}{*}{ Maize residue } & NR & $21.0 \pm 1.0 \mathrm{~b}$ & $26.5 \pm 0.9$ & $41.7 \pm 0.5 b$ & $16.3 \pm 0.5 \mathrm{a}$ & $3.9 \pm 0.7$ & $3.6 \pm 0.7$ & $3.7 \pm 0.1 \mathrm{~b}$ & $4.3 \pm 0.6$ \\
\hline & MR & $28.7 \pm 1.7 \mathrm{a}$ & $25.8 \pm 0.4$ & $47.5 \pm 0.7 \mathrm{a}$ & $13.5 \pm 0.4 \mathrm{~b}$ & $2.7 \pm 0.4$ & $1.9 \pm 0.1$ & $4.0 \pm 0.1 \mathrm{a}$ & $4.5 \pm 0.4$ \\
\hline \multirow[t]{5}{*}{$P$} & & 0.001 & 0.550 & $<0.001$ & 0.002 & 0.135 & 0.054 & 0.023 & 0.733 \\
\hline & NR & $19.6 \pm 0.4 \mathrm{~b}$ & $26.7 \pm 0.7$ & $40.9 \pm 0.6 b$ & $16.5 \pm 0.4 \mathrm{a}$ & $5.1 \pm 1.0$ & $3.1 \pm 0.4$ & $3.7 \pm 0.1 \mathrm{ab}$ & $4.0 \pm 0.4$ \\
\hline & $\mathrm{NR}+\mathrm{F}$ & $22.4 \pm 1.8 \mathrm{~b}$ & $26.3 \pm 1.8$ & $42.5 \pm 0.6 b$ & $16.1 \pm 1.1 \mathrm{ab}$ & $2.8 \pm 0.8$ & $4.2 \pm 1.5$ & $3.7 \pm 0.2 \mathrm{~b}$ & $4.6 \pm 1.3$ \\
\hline & MR & $26.2 \pm 2.4 \mathrm{ab}$ & $25.6 \pm 0.5$ & $46.9 \pm 1.0 \mathrm{a}$ & $13.7 \pm 0.6 \mathrm{ab}$ & $2.3 \pm 0.4$ & $2.1 \pm 0.2$ & $4.3 \pm 0.1 \mathrm{a}$ & $5.2 \pm 0.1$ \\
\hline & $\mathrm{MR}+\mathrm{F}$ & $31.3 \pm 2.1 \mathrm{a}$ & $26.0 \pm 0.7$ & $48.0 \pm 0.9 \mathrm{a}$ & $13.4 \pm 0.5 \mathrm{~b}$ & $3.1 \pm 0.8$ & $1.8 \pm 0.1$ & $3.8 \pm 0.1 \mathrm{ab}$ & $3.9 \pm 0.5$ \\
\hline Interaction $(P)$ & & 0.539 & 0.696 & 0.756 & 0.888 & 0.071 & 0.424 & 0.157 & 0.214 \\
\hline
\end{tabular}

Bold indicates significant at $p<0.05$

$C$ control without flood, $F$ flood, $N R$ non-residue application, $M R$ maize residue application $\left(8 \mathrm{Mg} \mathrm{ha}^{-1}\right)$, Anaerobes anaerobic bacteria, Arb. Myco. putative arbuscular mycorrhizal fungi 
(a) Variables

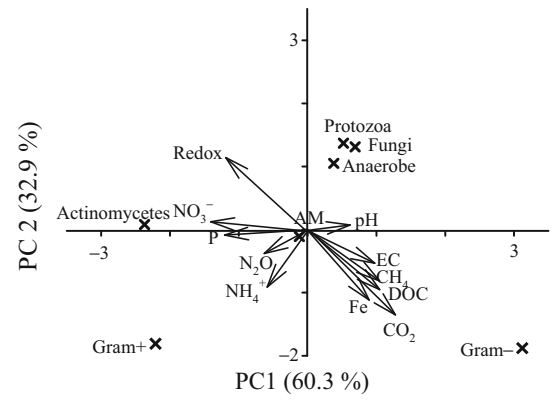

(b) Treatment separation after the flood phase

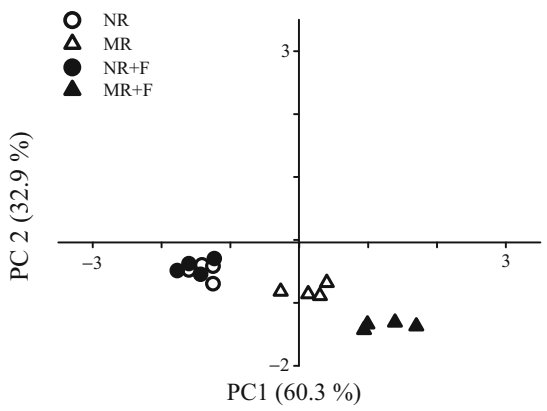

(c) Treatment separation after the soil recovery

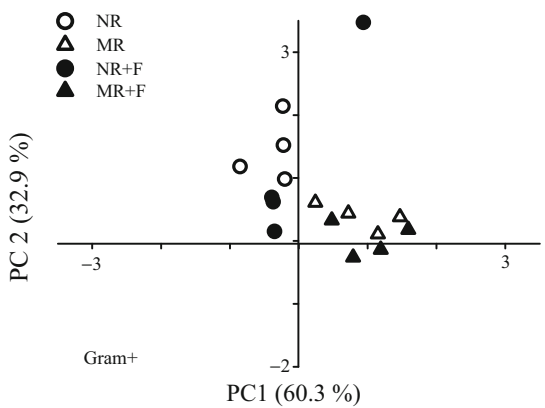

Fig. 5 Principal component analysis of microbial community PLFAs in response to flooding and crop residue addition $\left(8 \mathrm{Mg} \mathrm{ha}^{-1}\right)$. a Relationships between taxonomic groups (PLFAs, crosses, used to separate the different combination of treatments) and environmental variables (arrows, redox in soil, $\mathrm{pH}, \mathrm{EC}, \mathrm{P}, \mathrm{Fe}, \mathrm{NH}_{4}{ }^{+}, \mathrm{NO}_{3}{ }^{-}, \mathrm{DOC}$,

these may have implications for future fertilizer management and plant P availability (Kögel-Knabner et al. 2010).

\section{Soil greenhouse gas emissions}

Consistent with previous studies, the presence of maize residues and flooding caused major changes in net GHG emissions (Smith and Conen 2004); however, these effects did not persist long into the soil recovery phase. The greatest emissions occurred in the flooded treatments when crop residues were present. We ascribe this to the microbial use of the added $\mathrm{C}$, the consumption of $\mathrm{O}_{2}$ and a progressive drop in oxidationreduction potential that ultimately resulted in $\mathrm{CH}_{4}$ production (Hou et al. 2000). Maximal $\mathrm{CH}_{4}$ release occurred after floodwater removal probably from the release of $\mathrm{CH}_{4}$ trapped
$\mathrm{CH}_{4}, \mathrm{CO}_{2}, \mathrm{~N}_{2} \mathrm{O}$, showing their relations with different taxonomic groups); $\mathbf{b}$ treatment separation after the flood phase; and $\mathbf{c}$ treatment separation after the soil recovery phase. $N R$ control without flood or residues, $N R+F$ no residues with flooding, $M R$ maize residue application, $M R+F$ maize residue with flooding within the soil pores (Comas and Wright 2012). It is also likely that the abundance of alternative terminal electron acceptors (e.g. $\mathrm{NO}_{3}{ }^{-} \rightarrow \mathrm{Fe}^{3+} \rightarrow \mathrm{Mn}^{4+} \rightarrow \mathrm{SO}_{4}{ }^{2-}$ ) limited $\mathrm{CH}_{4}$ production in the first 6-8 weeks of flooding (Cheng et al. 2006). This is supported by the dynamics of $\mathrm{NO}_{3}{ }^{-}$loss, $\mathrm{Fe}^{2+}$ production and the visual presence of FeS around the crop residues. Our results therefore suggest that shorter periods of soil inundation ( $<4$ weeks) with no history of flooding should result in very low $\mathrm{CH}_{4}$ emissions, possibly due to the lack of a large methanogen community (Hansen et al. 2014). $\mathrm{CH}_{4}$ consumption can form an important part of the $\mathrm{CH}_{4}$ budget in some soils (Liu et al. 2016). As we did not directly evaluate this process, further work is required to clarify if methanotrophy is affected following floodwater removal. Flooding caused a major loss of soil $\mathrm{NO}_{3}{ }^{-}$; however, this did not translate into

Table 5 Effect of flooding and soil maize residues on plant height, leaf chlorophyll content (SPAD) and plant biomass parameters of maize plants grown in the different soil samples at the end of the flood recovery phase (4-week length). The experimental unit was a pot with two maize plants

\begin{tabular}{clllllll}
\hline Factor & & Height $(\mathrm{cm})$ & $\begin{array}{l}\text { SPAD } \\
\text { values }\end{array}$ & $\begin{array}{l}\text { Shoot dry } \\
\text { weight }(\mathrm{g})\end{array}$ & $\begin{array}{l}\text { Root dry } \\
\text { weight }(\mathrm{g})\end{array}$ & $\begin{array}{l}\text { Plant dry } \\
\text { weight (g) }\end{array}$ & $\begin{array}{l}\text { Ratio above } \\
\text { ground-biomass/root }\end{array}$ \\
\hline Flood & $\mathrm{C}$ & $56.6 \pm 1.0$ & $16.2 \pm 1.3$ & $2.45 \pm 0.16$ & $1.34 \pm 0.12$ & $3.78 \pm 0.25$ & $1.9 \pm 0.1$ \\
& $\mathrm{~F}$ & $54.3 \pm 1.9$ & $14.9 \pm 1.6$ & $2.30 \pm 0.17$ & $1.26 \pm 0.08$ & $3.55 \pm 0.21$ & $1.8 \pm 0.1$ \\
$P$ & & 0.184 & 0.386 & 0.498 & 0.531 & 0.452 & 0.833 \\
Maize residue & $\mathrm{NR}$ & $53.3 \pm 1.7 \mathrm{~b}$ & $13.2 \pm 1.4 \mathrm{~b}$ & $2.29 \pm 0.20$ & $1.41 \pm 0.12$ & $3.67 \pm 0.30$ & $1.6 \pm 0.1 \mathrm{~b}$ \\
& $\mathrm{MR}$ & $57.5 \pm 1.0 \mathrm{a}$ & $18.0 \pm 0.9 \mathrm{a}$ & $2.46 \pm 0.12$ & $1.20 \pm 0.06$ & $3.65 \pm 0.16$ & $2.1 \pm 0.1 \mathrm{a}$ \\
$P$ & & $\mathbf{0 . 0 2 8}$ & $\mathbf{0 . 0 0 6}$ & 0.431 & 0.128 & 0.948 & $\mathbf{0 . 0 1 3}$ \\
& $\mathrm{NR}$ & $56.4 \pm 1.3 \mathrm{ab}$ & $15.5 \pm 2.2 \mathrm{ab}$ & $2.58 \pm 0.31$ & $1.56 \pm 0.16$ & $4.11 \pm 0.42$ & $1.7 \pm 0.2$ \\
& $\mathrm{NR}+\mathrm{F}$ & $50.3 \pm 2.3 \mathrm{~b}$ & $10.9 \pm 0.7 \mathrm{~b}$ & $2.00 \pm 0.19$ & $1.25 \pm 0.16$ & $3.23 \pm 0.31$ & $1.6 \pm 0.1$ \\
& $\mathrm{MR}$ & $56.8 \pm 1.8 \mathrm{ab}$ & $16.9 \pm 1.6 \mathrm{a}$ & $2.33 \pm 0.13$ & $1.13 \pm 0.09$ & $3.45 \pm 0.21$ & $2.1 \pm 0.1$ \\
Interaction $(P)$ & $\mathrm{MR}+\mathrm{F}$ & $58.3 \pm 0.8 \mathrm{a}$ & $19.0 \pm 0.6 \mathrm{a}$ & $2.60 \pm 0.20$ & $1.27 \pm 0.07$ & $3.86 \pm 0.21$ & $2.1 \pm 0.2$ \\
\hline
\end{tabular}

Different letters indicate significant differences determined using Tukey HSD post hoc tests at the 0.05 probability level. Bold indicates significant at $p<0.05$ $C$ control without flood, $F$ flood, $N R$ non-residue application, $M R$ maize residue application $\left(8 \mathrm{Mg} \mathrm{ha}^{-1}\right)$ 
increased $\mathrm{N}_{2} \mathrm{O}$ emissions, presumably due to complete denitrification (to $\mathrm{N}_{2}$ ) or immobilization within the microbial biomass (Baggs et al. 2000; Chen et al. 2013; Li et al. 2013). This is consistent with the lack of $\mathrm{O}_{2}$, the high $\mathrm{C}: \mathrm{N}$ ratio of our crop residues (Gentile et al. 2008) and the low $\mathrm{NH}_{4}{ }^{+}$concentrations in our soil solution (Rice and Tiedje 1989). $\mathrm{N}_{2} \mathrm{O}$ emissions were greatest in the absence of crop residues. In the unflooded treatment, this could arise from the simultaneous operation of nitrification and denitrification processes within the soil matrix (Gentile 2008; Bateman and Baggs 2005; ButterbachBahl et al. 2013), while under flooding, we expect that denitrification dominates (Amend and Shock 2001).

Flooding has been shown to either promote or reduce $\mathrm{CO}_{2}$ emissions depending upon land management regime (Aulakh et al. 2001; Li et al. 2004; Loeb et al. 2008). Although a reduction in the production of $\mathrm{CO}_{2}$ was expected due to the increase in the salinity of soil solution observed when the flooded soil was amended with maize residues (high ratio $\mathrm{C} /$ N; Hasbullah and Marschner 2015), in our experiment, inundation caused little change in net $\mathrm{CO}_{2}$ emissions. The similar rates of $\mathrm{CO}_{2}$ production at the end of the experiment are also consistent with a lack of effect of flooding on soil microbial function. Studies in which rice straw was incorporated into the soil (Tang et al. 2016) have shown that the production of $\mathrm{CH}_{4}$ and $\mathrm{CO}_{2}$ under anaerobic conditions were lowest at higher temperatures because the residues were highly decomposed due to the previous aerobic conditions. Therefore, as our experiment was developed under a simulated spring flood event, the production of these two gases was expected. The results presented here also suggest that long-term flooding of lowlying agricultural areas should be accounted for within national GHG inventory reporting.

\section{Soil microbial community biomass and composition}

Although not observed in many previous studies involving crop residues, the presence of maize stover increased the size of the microbial biomass and also induced a shift in community composition (Hoyle and Murphy 2006; Sall et al. 2015; Zhao et al. 2016). We ascribe this growth to the high relative abundance of $\mathrm{N}$ and $\mathrm{P}$ and the removal of $\mathrm{C}$ limitation within the system (Cayuela et al. 2009). These microbial community shifts were further enhanced by flooding. Our results are in partial agreement with Bossio and Scow $(1995,1998)$ and Unger et al. (2009) who showed little effect of flooding on the microbial biomass, but that it did induce shifts in the PLFA profile. Consistent with the reduction in oxidation-reduction potential, release of $\mathrm{Fe}^{2+}$ and production of $\mathrm{CH}_{4}$, we showed an increase in the PLFA marker for anaerobic bacteria and a reduction in obligate aerobes in the flooded treatments (Reichardt et al. 2001). The increase in DOC in the flooded treatments is also consistent with the lack of $\mathrm{O}_{2}$ required to promote enzymes involved in lignin breakdown (e.g. phenol oxidase) and the production of humic-rich DOC. The effects of flooding largely disappeared after the soil recovery phase. This is consistent with the other soil quality indicator values returning back to those seen in the unflooded controls. Although we cannot say whether flooding induced the loss of individual species, the high degree of functional redundancy within the community and the lack of major changes in PLFA profiles suggest that flooding did not cause irreversible changes in the community. Further work is required, however, to look at potential changes in keystone species involved in nutrient cycling (e.g. $\mathrm{N}$-fixers, nitrifiers, denitrifiers, mycorrhizal fungi) and the potential changes in plant pests and diseases (e.g. nematodes, damping-off).

\section{Plant performance}

Here, we show that in comparison to the presence or absence of crop residues, maize growth was not greatly influenced by flood history. This supports field observations that a single flood event does not cause an irreversible loss in soil function and its ability to support plant growth, at least in the short term (Defra 2014). Outside of rice cropping systems, however, the longer-term post-consequences of extreme flood events on crop growth still remain poorly understood.

The period of recovery used here was designed to simulate the earliest time at which farmers would intervene after floodwater removal (based on field observation). This seems appropriate given that most soil quality indicators (e.g. GHG emissions, $\mathrm{DOC}, \mathrm{Fe}, \mathrm{P}$, oxidation-reduction potential) had returned to levels close to the unflooded controls by $5-8$ weeks. Our results also suggest that any phytotoxic substances created under flooding had either been biodegraded (e.g. volatile fatty acids), oxidation-reduction potential-sensitive metals had reprecipitated (e.g. $\mathrm{Mn}^{2+} \rightarrow \mathrm{MnO}_{2}$ ), or that they had become readsorbed to the solid phase (e.g. Zn; Du Laing et al. 2009). This is also supported by the lack of observed effect of flooding on root or foliar metal content. In our experience, farmers may wait up to 9 months before attempting to reestablish a crop on land that has been unduly flooded, due to the risk of causing compaction when tilling a wet soil. Under these circumstances, it is likely that all traces of phytotoxins will have disappeared from the soil (Chou and Lin 1976).

\section{Conclusions and implications for management}

As expected, extreme flooding had a major impact, albeit short term, on soil functioning. Further, the evidence presented here suggests that long-term flooding in the presence of crop residues may have more severe consequences, in terms of soil quality, than if residues are not present. This is also supported by our own empirical field observations. A key question is therefore whether we should alter land management practices in high-flood-risk areas to limit their 
detrimental impact. By their nature, extreme flooding events are almost impossible to predict. In addition, it is notoriously difficult to communicate the risks of extreme weather events to farmers and persuade them to alter their land management practices (Haigh et al. 2015; Hyland et al. 2016). One potential option is that farmers in high-flood-risk areas should not incorporate crop residues into the soil or that they should be removed at harvest (e.g. by burning). While theoretically possible, this option directly contravenes current advice, albeit controversial (Mitchell et al. 2016), to incorporate residues to build up soil organic matter reserves and improve general soil health. Residue removal could also be environmentally damaging and leave the soil more prone to both water and wind erosion (Xin et al. 2016). A more radical option would be to prevent cereal cropping in high-flood-risk areas and shift to a less flood-sensitive land use (e.g. permanent grassland with high diversity; Natural England 2014; Wright et al. 2017). As with most land management options, however, there are trade-offs and the positive aspects should also be emphasized. While residues increase GHG emissions tenfold on a GWP basis, they may be beneficial in reducing $\mathrm{NO}_{3}{ }^{-}$ leaching and potentially indirect $\mathrm{N}_{2} \mathrm{O}$ emissions, both of which are universal goals for sustainable agriculture.

The work undertaken here was limited to one soil type studied under very controlled conditions in the laboratory. Further work should therefore investigate a greater range of soil types and flood scenarios, especially under realistic field conditions. In addition, studies should also include a wider range of organic residues (e.g. differing in C-to-N ratio) as this is likely to have a major impact on net GHG emissions and other soil quality indicators. Finally, as green cover crops offer great potential to protect soils from intense rainfall and flood events (Boardman 2015), further work should investigate whether their benefits exist further than just limiting erosion or whether in fact they further exacerbate the negative consequences of flooding on soil health.

Acknowledgements This work was supported by the UK Natural Environment Research Council (NERC) and Department for Environment, Food and Rural Affairs (DEFRA) under Project NE/ M005143/1 and by the "Fundación Ramón Areces" (Antonio Rafael Sánchez-Rodríguez is supported by the postdoctoral scholarship "Beca para ampliación de estudios en el extranjero en materia de Ciencias de la Vida y de la Materia"). Additional support was provided by the Welsh Government-funded Sêr Cymru National Research Network for Low Carbon, Energy and Environment under the Climate-Smart Grass programme.

Open Access This article is distributed under the terms of the Creative Commons Attribution 4.0 International License (http:// creativecommons.org/licenses/by/4.0/), which permits unrestricted use, distribution, and reproduction in any medium, provided you give appropriate credit to the original author(s) and the source, provide a link to the Creative Commons license, and indicate if changes were made.

\section{References}

Adrian WJ (1973) A comparison of a wet pressure digestion method with other commonly used wet and dry-ashing methods. Analyst 98:213216

AHDB (2015) Growing and feeding maize silage for better returns. AHDB Beef \& Lamb, Agriculture and Horticulture Development Board, Kenilworth

Amend JP, Shock EL (2001) Energetics of overall metabolic reactions of thermophilic and hyperthermophilic Archea and Bacteria. FEMS Microbiol rev 25:175-243

Aulakh MS, Khera TS, Doran JW, Bronson KF (2001) Denitrification, $\mathrm{N}_{2} \mathrm{O}$ and $\mathrm{CO}_{2}$ fluxes in rice-wheat cropping system as affected by crop residues, fertilizer $\mathrm{N}$ and legume green manure. Biol Fert Soils 34:375-389

Baggs EM, Rees RM, Smith KA, Vinten AJA (2000) Nitrous oxide emission from soils after incorporating crop residues. Soil use Manage 16:82-87

Bartelt-Ryser J, Joshi J, Schmid B, Brandl H, Balser T (2005) Soil feedbacks of plant diversity on soil microbial communities and subsequent plant growth. Perspect Plant Ecol Evol Syst 7:27-49

Bateman EJ, Baggs EM (2005) Contributions of nitrification and denitrification to $\mathrm{N}_{2} \mathrm{O}$ emissions from soils at different water-filled pore space. Biol Fert Soils 41:379-388

Boardman J (2015) Extreme rainfall and its impact on cultivated landscapes with particular reference to Britain. Earth Surf Proc Land 40: $2121-2130$

Boardman J, Vandaele K (2016) Effect of the spatial organization of land use on muddy flooding from cultivated catchments and recommendations for the adoption of control measures. Earth Surf Proc Land 41:336-343

Bossio DA, Scow KM (1995) Impact of carbon and flooding on the metabolic diversity of microbial communities in soils. Appl Environ Microbiol 61:4043-4050

Bossio DA, Scow KM (1998) Impacts of carbon and flooding on soil microbial communities: phospholipid fatty acid profiles and substrate utilization patterns. Microb Ecol 35:265-278

Bünemann EK, Oberson A, Liebisch F, Keller F, Annaheim KE, Huguenin-Elie O, Frossard E (2012) Rapid microbial phosphorus immobilization dominates gross phosphorus fluxes in a grassland soil with low inorganic phosphorus availability. Soil Biol Biochem 51:84-95

Butterbach-Bahl K, Baggs EM, Dannenmann M, Kiese R, ZechmeisterBoltenstern S (2013) Nitrous oxide emissions from soils: how well do we understand the processes and their controls? Philos Trans Royal Soc B 368:20130122

Cayuela ML, Sinicco T, Mondini C (2009) Mineralization dynamics and biochemical properties during initial decomposition of plant and animal residues in soil. Appl Soil Ecol 41:118-127

Chen H, Li X, Hu F, Shi W (2013) Soil nitrous oxide emissions following crop residue addition: a meta-analysis. Glob Change Biol 19:29562964

Cheng WG, Yagi K, Sakai H, Kobayashi K (2006) Effects of elevated atmospheric $\mathrm{CO}_{2}$ concentrations on $\mathrm{CH}_{4}$ and $\mathrm{N}_{2} \mathrm{O}$ emission from rice soil: an experiment in controlled-environment chambers. Biogeochem 77:351-373

Chou CH, Lin HJ (1976) Autointoxication mechanism of Oryza sativa L. phytotoxic effects of decomposing rice residues in soil. J Chem Ecol 2:353-367

Comas X, Wright W (2012) Heterogeneity of biogenic gas ebullition in subtropical peat soils is revealed using time-lapse cameras. Water Resour Res 48:W04601

Damon PM, Bowden B, Rose T, Rengel Z (2014) Crop residue contributions to phosphorus pools in agricultural soils: a review. Soil Biol Biochem 74:127-137 
Davidson EA (1991) Fluxes of nitrous oxide and nitric oxide from terrestrial ecosystems. In: Rogers JE, Whitman WB (eds) Microbial production and consumption of greenhouse gases: methane, nitrogen oxides, and halomethanes. ASM Press, American Society for Microbiology, Washington DC, pp 219-235

de Vries FT, Liiri ME, Bjornlund L, Bowker MA, Christensen S, Setala HM, Bardgett RD (2012) Land use alters the resistance and resilience of soil food webs to drought. Nat Clim Chang 2:276-280

Defra (2014) Legacy effects of extreme flood events on soil quality and ecosystem functioning: Project LM0316 Final Report. Department for Environment, Food \& Rural Affairs, London

Devevre OC, Horwath WR (2000) Decomposition of rice straw and microbial carbon use efficiency under different soil temperatures and moistures. Soil Biol Biochem 32:1773-1785

Doring TF, Brandt M, Hess J, Finckh MR, Saucke H (2005) Effects of straw mulch on soil nitrate dynamics, weeds, yield and soil erosion in organically grown potatoes. Field Crops res 94:238-249

Du Laing G, Rinklebe J, Vandecasteele B, Meers E, Tack FMG (2009) Trace metal behaviour in estuarine and riverine floodplain soils and sediments: a review. Sci tot Environ 407:3972-3985

FAO (2015) World reference base for soil resources 2014. World soil resources reports 106. Food and Agriculture Organization of the United Nations, Rome

Frimpong KA, Baggs EM (2010) Do combined applications of crop residues and inorganic fertilizer lower emission of $\mathrm{N}_{2} \mathrm{O}$ from soil? Plant Soil 26:421-424

Gentile R, Vanlauwe B, Chivenge P, Six J (2008) Interactive effects from combining fertilizer and organic residue inputs on nitrogen transformations. Soil Biol Biochem 40:2375-2384

Giesler R, Lundström US (1993) Soil solution chemistry - the effects of bulking soil samples and spatial variation. Soil Sci Soc am J 57: 1283-1288

Gotoh S, Patrick WH (1974) Transformation of iron in a waterlogged soil as influenced by redox potential and pH. Soil Sci Soc am J 38:66-71

Haigh T, Morton LW, Lemos MC, Knutson C, Prokopy LS, Lo YJ, Angel J (2015) Agricultural advisors as climate information intermediaries, exploring differences in capacity to communicate climate. Weather Clim Soc 7:83-93

Hansen M, Clough TJ, Elberling B (2014) Flooding-induced emission bursts controlled by $\mathrm{pH}$ and nitrate in agricultural soils. Soil Biol Biochem 69:17-24

Hansen EM, Munkholm LJ, Olesen JE, Melander B (2015) Nitrate leaching, yields and carbon sequestration after noninversion tillage, catch crops, and straw retention. J Environ Qual 44:868-881

Hasbullah H, Marschner P (2015) Residue properties influence the impact of salinity on soil respiration. Biol Fert Soils 51:99-111

Hou AX, Hen GX, Wang ZP, Van Cleemput O, Patrick WH Jr (2000) Methane and nitrous oxide emissions form a rice field in relation to soil redox and microbiological processes. Soil Sci Soc Am J 64: 2180-2186

Hoyle FC, Murphy DV (2006) Seasonal changes in microbial function and diversity associated with stubble retention versus burning. Aust J Soil res 44:407-423

Hueso S, Hernández T, García C (2011) Resistance and resilience of the soil microbial biomass to severe drought in semiarid soils: the importance of organic amendments. Appl Soil Ecol 50:27-36

Hyland JJ, Jones DL, Parkhill KA, Williams AP (2016) Farmers' perceptions of climate change, identifying types. Agric Human Values 33: 323-339

IPCC (2013) Climate change 2013: the physical science basis. Contribution of working group I to the Fifth Assessment Report of the Intergovernmental Panel on climate change. In: Stocker TF, Qin D, Plattner GK, Tignor M, Allen SK, Boschung J, Nauels A, Xia Y, Bex V, Midgley PM (eds) Cambridge University Press. Cambridge, United Kingdom and New York, NY, USA, p 1535
Kieft TL, Ringelberg DB, White DL (1994) Changes in ester-linked phospholipid fatty acid profiles of subsurface bacteria during starvation and desiccation in a porous medium. Appl Environ Microbiol 60:3292-3299

Kogel-Knabner I, Amelung W, Cao ZH, Fiedler S, Frenzel P, Jahn R, Kalbitz K, Kolbl A, Schloter M (2010) Biogeochemistry of paddy soils. Geoderma 157:1-14

Kyuma K (2004) Paddy soil science. Trans Pacific Press Pty Ltd, Balwyn

Li X, Hu F, Shi W (2013) Plant material addition affects soil nitrous oxide production differently between aerobic and oxygen-limited conditions. Appl Soil Ecol 64:91-98

Li CS, Mosier A, Wassmann R, Cai ZC, Zheng XH, Huang Y, Tsuruta H, Boonjawa J, Lantin R (2004) Modeling greenhouse gas emissions from rice-based production systems: sensitivity and upscaling. Glob Biogeochem cy 18:GB1043

Li X, Wei X (2014) Analysis of the relationship between soil erosion risk and surplus floodwater during flood season. J Hydrol Eng 19:1294 1311

Liu J, Chen X, Zhan A, Luo S, Chen H, Jiang H, Huang X, Li S (2016) Methane uptake in semiarid farmland subjected to different mulching and nitrogen fertilization regimes. Biol Fert Soils 52: 941-950

Loeb R, Lamers LPM, Roelofs JGM (2008) Effects of winter versus summer flooding and subsequent desiccation on soil chemistry in a riverine hay meadow. Geoderma 145:84-90

Loeppert RH, Inskeep WP (1996) Iron. In: Sparks DL (ed) Methods of soil analysis, Part, vol 3. Chemical Methods. ASA/SSSA, Madison, WI, pp 639-664

Mackenzie AF, Fan MS, Cadrin F (1998) Nitrous oxide emission in three years as affected by tillage, corn-soybean-alfalfa rotations, and nitrogen fertilization. J Environ Qual 27:698-703

Madan R, Pankhurst C, Hawke B, Smith S (2002) Use of fatty acids for identification of AM fungi and estimation of the biomass of AM spores in soil. Soil Biol Biochem 34:125-128

Met Office (2014) The recent storms and floods in the UK. Met Office, Exeter

Miranda KM, Espey MG, Wink DA (2001) A rapid simple spectrophotometric method for simultaneous detection of nitrate and nitrite. Nitric Oxide 5:62-71

Mirza MMQ (2011) Climate change, flooding in South Asia and implications. Reg Environ Chang 11:S95-S107

Mitchell E, Scheer C, Rowlings DW, Conant RT, Cotrufo MF, van Delden L, Grace PR (2016) The influence of above-ground residue input and incorporation on GHG fluxes and stable SOM formation in a sandy soil. Soil Biol Biochem 101:104-113

Muchan K, Lewis M, Hannaford J, Parry S (2015) The winter storms of $2013 / 2014$ in the UK, hydrological responses and impacts. Weather 70:55-61

Mulvaney RL (1996) Nitrogen —inorganic forms. In: Sparks DL (ed) Methods of soil analysis, Part, vol 3. Chemical Methods. SSSA, Madison, WI, pp 1123-1184

Murphy J, Riley JP (1962) A modified single solution method for the determination of phosphate in natural waters. Anal Chim Acta 27: $31-36$

Natural England (2014) An assessment of the effects of the 2013-14 flooding on the wildlife and habitats of the Somerset levels and moors: Report JP007. Natural England, Worcester

Niklaus PA, Alphei J, Ebersberger D, Kampichler D, Kandeler E, Tscherko D (2003) Six years of in situ $\mathrm{CO}_{2}$ enrichment evoke changes in soil structure and soil biota of nutrient-poor grassland. Glob Chang Biol 9:585-600

Niu S, Luo Y, Li D, Cao S, Xia J, Li J, Smith MD (2014) Plant growth and mortality under climatic extremes: an overview. Environ Exp bot 98: $13-19$ 
Olsson PA, Thingstrup I, Jakobsen I, Baath F (1999) Estimation of the biomass of arbuscular mycorrhizal fungi in a linseed field. Soil Biol Biochem 31:1879-1887

Pall P, Aina T, Stone DA, Stott PA, Nozawa T, Hilberts AGJ, Lohmann D, Allen MR (2011) Anthropogenic greenhouse gas contribution to flood risk in England and Wales in autumn 2000. Nature 470:382385

Paul EA, Clark FE (1996) Soil microbiology and biochemistry. Academic Press, San Diego

Ratledge C, Wilkinson SG (1988) Microbial lipids. Academic Press, London

Reichardt W, Briones A, de Jesus R, Padre B (2001) Microbial population shifts in experimental rice systems. Appl Soil Ecol 17:151-163

Rice CW, Tiedje JM (1989) Regulation of nitrate assimilation by ammonium in soils and in isolated soil micro-organisms. Soil Biol Biochem 21:597-602

Rinklebe J, Knox AS, Paller M (2016) Trace elements in waterlogged soils and sediments. Advances in trace elements in the environment. CRC Press, Boca Raton

Sall SN, Ndour NYB, Diedhiou-Sall S, Dick R, Chotte JL (2015) Microbial response to salinity stress in a tropical sandy soil amended with native shrub residues or inorganic fertilizer. J Environ Manag $161: 30-37$

Slater LJ, Villarini G (2016) Recent trends in US flood risk. Geophys res Lett 43:12428-12436

Smith KA, Conen F (2004) Impacts of land management on fluxes of trace greenhouse gases. Soil use Manag 20:255-263

Tang S, Cheng W, Hu R, Guigue J, Kimani SM, Tawarava K, Xu X (2016) Simulating the effects of soil moisture in the off-rice season on rice straw decomposition and subsequent $\mathrm{CH}_{4}$ production during the growth season in a paddy soil. Biol Fert Soils 52:739-748

Tong SL, Berry HL, Ebi K, Hilary B, Hu WB, Green D, Hanna E, Wang ZQ, Butler CD (2016) Climate change, food, water and population health in China. Bull World Health Organ 94:759-765
Unger IM, Kennedy AC, Muzika RM (2009) Flooding effects on soil microbial communities. Appl Soil Ecol 42:1-8

Volosciuk C, Maraun D, Semenov VA, Tilinina N, Gulev SK, Latif M (2016) Rising Mediterranean Sea surface temperatures amplify extreme summer precipitation in Central Europe. Sci rep 6:32450

Wintermans JFGM, de Mots A (1965) Spectrophotometric determination of chlorophyll $\mathrm{a}$ and $\mathrm{b}$ and their pheophytins in ethanol. Biochim Biophys Acta 109:448-453

WMO (2013) The global climate 2001-2010. A decade of climate extremes. Word Meteorological Organization, Geneva

Wright AJ, de Kroon H, Visser EJW, Buchmann T, Ebeling A, Eisenhauer $\mathrm{N}$, Fischer C, Hildebrandt A, Ravenek J, Roscher C, Weigelt A, Weisser W, Voesenek LA, Mommer L (2017) Plants are less negatively affected by flooding when growing in species-rich plant communities. New Phytol 213:944-955

Xin Y, Xie Y, Liu YX, Liu HY, Ren XY (2016) Residue cover effects on soil erosion and the infiltration in black soil under simulated rainfall experiments. J Hydrol 543:651-658

Yellen B, Woodruff JD, Kratz LN, Mabee SB, Morrison J, Martini AM (2014) Source, conveyance and fate of suspended sediments following hurricane Irene. New England, USA. Geomorphology 226:124 134

Yuan Z, Yang ZY, Yan DH, Yin J (2017) Historical changes and future projection of extreme precipitation in China. Theor Appl Climatol 127:393-407

Zelles L (1999) Fatty acids patterns of phospholipids and lipopolysaccharides in the characterization of microbial communities in soil: a review. Biol Fert Soils 29:111-129

Zhao BZ, Zhang JB, Yu YY, Karlen DL, Hao XY (2016) Crop residue management and fertilization effects on soil organic matter and associated biological properties. Environ Sci Pollut res 23:1758117591 